\title{
Differentiating Responses of Lung Cancer Cell Lines to Doxorubicin Exposure: In Vitro Raman Micro Spectroscopy, Oxidative Stress and bcl-2 Protein Expression
}

\author{
Zeineb Farhane \\ Technological University Dublin, zeinab.farhane@mydit.ie \\ Franck Bonnier \\ Technological University Dublin, Franck.Bonnier@tudublin.ie \\ Marcus A. Maher \\ Technological University Dublin
}

See next page for additional authors

Follow this and additional works at: https://arrow.tudublin.ie/radart

Part of the Medicine and Health Sciences Commons

\section{Recommended Citation}

Farhane, Z., Bonnier, F. \& Maher, M.A. (2017). Differentiating responses of lung cancer cell lines to Doxorubicin exposure: in vitro Raman micro spectroscopy, oxidative stress and bcl-2 protein expression. Journal of Biophotonics, vol. 10, no. 1, pp. 151-165. doi:10.1002/jbio.201600019

This Article is brought to you for free and open access by the Radiation and Environmental Science Centre at ARROW@TU Dublin. It has been accepted for inclusion in Articles by an authorized administrator of ARROW@TU Dublin. For more information, please contact arrow.admin@tudublin.ie, aisling.coyne@tudublin.ie, gerard.connolly@tudublin.ie.

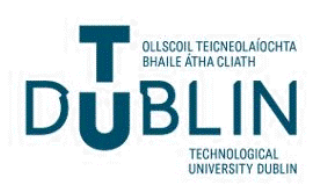




\section{Authors}

Zeineb Farhane, Franck Bonnier, Marcus A. Maher, Jane Bryant, Alan Casey, and Hugh J. Byrne

This article is available at ARROW@TU Dublin: https://arrow.tudublin.ie/radart/46 


\section{Differentiating responses of lung cancer cell lines to Doxorubicin}

exposure: in vitro Raman micro spectroscopy, oxidative stress and bcl-2 protein expression.

Zeineb Farhane ${ }^{1,2^{*}}$, Franck Bonnier ${ }^{3}$, Marcus Alexander Maher ${ }^{1,2}$, Jane Bryant ${ }^{1}$, Alan Casey ${ }^{1}$ and Hugh James Byrne ${ }^{1}$

${ }^{1}$ FOCAS Research Institute, Dublin Institute of Technology, Kevin Street, Dublin 8, Ireland. ${ }^{2}$ School of Physics, Dublin Institute of Technology, Kevin Street, Dublin 8, Ireland.

${ }^{3}$ Université François-Rabelais de Tours, Faculty of Pharmacy, EA 6295 Nanomédicaments et Nanosondes, 31 avenue Monge, 37200 Tours, France

*Corresponding author: zeineb.farhane@mydit.ie

\section{Abstract:}

The potential of Raman micro spectroscopy as an in vitro, non-invasive tool for clinical applications has been demonstrated in recent years, specifically for cancer research. To further illustrate its potential as a high content and label free technique, it is important to show its capability to elucidate drug mechanisms of action and cellular resistances. In this study, cytotoxicity assays were employed to establish the toxicity profiles for $24 \mathrm{hr}$ exposure of lung cancer cell lines, A549 and Calu-1, to the commercially available drug, doxorubicin (DOX). Raman spectroscopy, coupled with Confocal Laser Scanning Microscopy and Flow Cytometry, was used to track the DOX mechanism of action, at a subcellular level, and to study the mechanisms of cellular resistance to DOX. Biomarkers related to the drug mechanism of action and cellular resistance to apoptosis, namely reactive oxygen species (ROS) and bcl-2 protein expression, respectively, were also measured and correlated to Raman spectral profiles. Calu-1 cells are shown to exhibit spectroscopic signatures of both direct DNA damage due to intercalation in the nucleus and indirect damage due to oxidative stress in the cytoplasm, whereas the A549 cell line only exhibits signatures of the former mechanism of action. 


\section{Abstract Figure:}
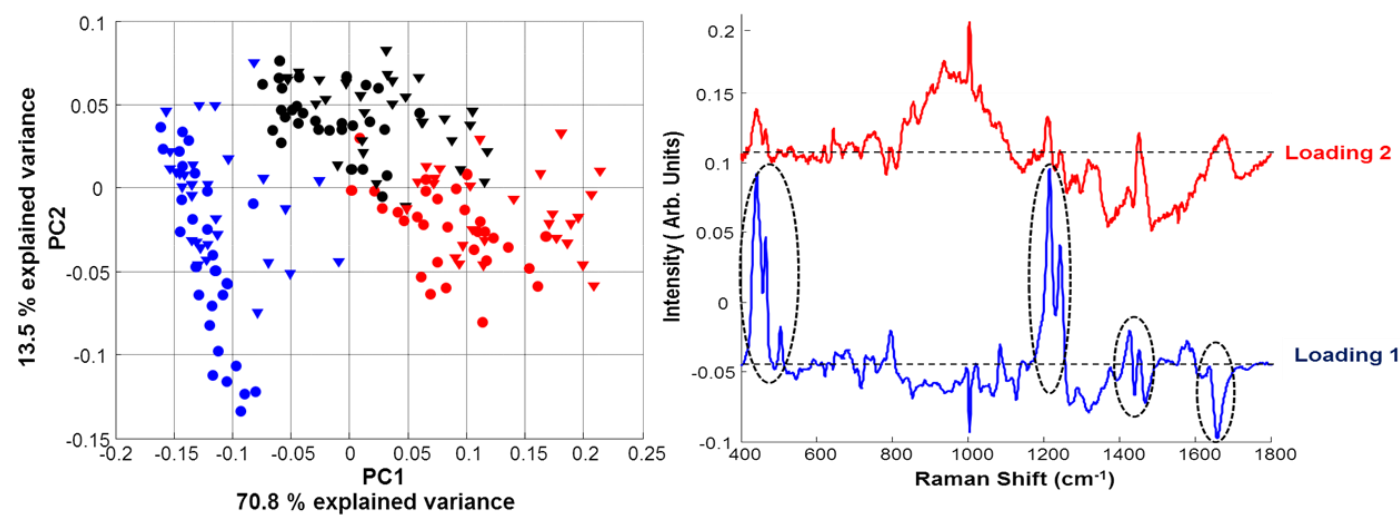

PCA of nucleolar, nuclear and cytoplasmic regions of A549 and Calu-1 with corresponding loadings of PC1 and PC2

\section{Short title:}

Differentiating responses of lung cancer cell lines to Doxorubicin: Raman, bcl-2 protein and ROS expression

Z. Farhane et al.

Keywords: Raman micro spectroscopy, Doxorubicin, Cytotoxicity, Confocal Laser Scanning Microscopy, Flow Cytometry, bcl-2 protein, ROS, drug resistance. 


\section{Introduction:}

The potential of Raman micro spectroscopy as a non-destructive, label free, analytical technique in clinical, pharmaceutical development and biomedical applications, based on its ability to monitor the chemical, bio-physiological and physical changes at the molecular level, has been demonstrated. [1-3]

Among the possible applications of Raman micro spectroscopy in the clinical setting, cancer research and diagnostics remain among the most promising, including cancer detection and typing, for example oral $[4,5]$, gastric $[6,7]$, breast $[8,9]$, cervical $[10,11]$, skin [12] cancers as well as therapeutic follow up and response to chemotherapeutic drugs . [13, 14]

Indeed, Raman micro spectroscopy has been used not only to detect and monitor drugs inside cells at a subcellular level but also to fingerprint the cellular response to this exposure and the adverse drug effect [15]. Therefore, it can be developed as a companion diagnostic tool, providing details about drug efficacy and safety, as detailed in the US FDA guidance document issued in August 2014, which defines such a tool as an in vitro diagnostic device that provides information that is essential for the safe and effective use of a corresponding therapeutic product. [16, 17] The use of in vitro models is also consistent with EU and US policies to reduce the use of animals for scientific testing (EU Directive-2010/63/EU and US Public Law 106-545, 2010, 106th Congress) and thus the demonstration of Raman micro spectroscopy as a companion diagnostic for screening and analysis of commercial chemotherapeutic agents could be of significant importance in cancer research.

To this end, Doxorubicin (DOX), which belongs to the anthracycline family, commercially known as Adriamycin, and widely prescribed as a chemotherapeutic antibiotic, was employed as a model compound. Despite its extensive clinical use, DOX has many toxic and chronic side effects, notably cardiotoxicity [18], and therefore it is important to understand how it effects cancer cells and the sources of cellular resistance in order to optimise its clinical efficacy and reduce its toxicity to the surrounding environment.

Routinely used clinically to treat aggressive and metastatic tumours, including lung cancers, DOX involves different mechanisms of action, not fully understood. Although originally thought to inhibit tumour cell proliferation by DNA intercalation, over the years, many other mechanisms of action have been identified, such as topoisomerase II inhibition, the formation of DNA adducts[19, 20], inhibition of DNA methyltransferase [21] and Transforming Growth Factor- $\beta 1$ (TGF $\beta 1$ ) [22] and oxidative stress by generation of reactive oxygen species (ROS). The latter relates to its cytosolic metabolism and reduction to the doxorubicin 
semiquinone radical, leading to generation of superoxide and hydrogen peroxide, increased intracellular oxidative stress $[23,24]$, changes in the mitochondrial permeability, a release of cytochrome $\mathrm{C}$ which activate caspase effectors causing DNA damage. [20, 25] All these mechanisms of action lead to apoptosis, a programmed cell death or "cellular suicide", as a way to remove unwanted cells exhibiting dangerous anarchic development as tumour cells, initiated extrinsically by the engagement of receptors at cytoplasmic membrane or intrinsically by, for example, DNA damage, resulting from chemotherapy or oxidative stress or growth factor withdrawal. [26-29]

The mitochondrial or intrinsic apoptosis pathway is controlled by two groups of proteins; pro-apoptotic and anti-apoptotic. Among the latter category, the bcl-2 (B cell lymphoma) family, an intracellular membrane protein generated as a direct result of DNA damage, represents the most important anti-apoptotic protein, which binds to almost all pro-apoptotic proteins [30] and so regulates the mitochondrial apoptosis pathways by mediating the mitochondrial outer membrane permeability (MOMP) and by local inhibition of free radical production suggesting an anti-oxidant mechanism, inhibiting cell apoptosis as a results including drug-induced. [31-36]

Any alteration, resistance or failure in apoptosis, due for example, to a higher expression of anti-apoptotic protein bcl-2, allows tumour cells to survive and proliferate, leading to resistance to chemotherapy and a poor clinical prognosis. [37-39] The cytological mechanisms of drug resistance in cancer cells can be an increased detoxification of anticancer drugs by the glutathione system, a defective apoptotic pathway, enhanced DNA damage repair or increased tolerance to DNA damage leading to suppression of apoptosis, elevated expression of anti-apoptotic genes and proteins, decreased uptake of water-soluble drugs and enhanced drug efflux from cancer cells mediated by ATP-binding cassette (ABC) transporters. [40, 41]

Understanding the relative contributions of this array of potential contributing mechanisms is a challenging task, requiring a manifold of parallel analytical techniques and assays, which are costly and time consuming. Previous studies have shown that Raman micro spectroscopy is not only able to discriminate between cancer cells according to nucleolar region [42] but also to detect drugs inside cells, their effects on cell biology and the physiological response of the cell to this exposure. [14] The aim of the current study extend the previous investigations to fingerprint the DOX mechanism of action on non-small cell lung cancer cell lines A549 and Calu-1 and the different cellular response using Raman micro spectroscopy and to investigate its ability to differentiate the effect of the chemotherapeutic drug in the two 
different lung cancer cell lines. To support this spectroscopic analysis, Confocal Laser Scanning Microscopy was employed to monitor the subcellular DOX localisation and bcl-2 expression due to DNA damage was measured using Flow Cytometry and correlated to cellular levels of ROS, in relation to DOX mechanism of action. All observations were related to changes in Raman features for the three cellular compartments nucleolus, nucleus and cytoplasm.

\section{Materials and methods:}

\section{Materials:}

A549 human lung adenocarcinoma cells with the alveolar type II phenotype were obtained from ATTC (Manassas, VA, USA) and Calu-1 human lung epidermoid carcinoma cell line, was kindly provided by Dr. Josep Sulé-Suso, Institute for Science \& Technology in Medicine, Keele University, Guy Hilton Research Centre UK and Cancer Centre, Royal Stoke University Hospital, University Hospitals of North Midlands, UK.

Doxorubicin hydrochloride ${ }^{\circledR}$ powder (Sigma Life Sciences, Ireland) was diluted in $1 \mathrm{~mL}$ sterile water to the required concentration $(17.25 \mathrm{mM})$.

Alamar blue $(\mathrm{AB})$ (10X ready to use solution) and 3-[4,5-dimethylthiazol-2-yl]-2,5-diphenyl tetrazolium bromide (MTT) were obtained from Sigma Aldrich, Ireland.

For cytotoxicity assays an $\mathrm{AB} / \mathrm{MTT}$ solution, $1.5 \mathrm{~mL}$ of $\mathrm{AB}$ and $3 \mathrm{~mL}$ of MTT stock solution $(2.5 \mathrm{mg} / \mathrm{mL}, 25 \mathrm{mg}$ MTT/10mL PBS) in $30 \mathrm{~mL}$ of fresh medium was prepared.

Fixation/permeabilization kit, BD Cytofix/Cytoperm (BD 554714), and FITC Mouse AntiHuman bcl-2 set with an IgG1 isotype control (BD 556357) were purchased from BD Biosciences, Ireland.

Nucred $^{\circledR}$ live 647 ReadyProbes ${ }^{\circledR}$ Reagent, used to image the cellular nucleus, and [5(6)Carboxy-2',7'-dichlorodihydrofluorescein diacetate] (Carboxy-H2DCFDA) dye, used for the detection of Reactive oxygen species (ROS), were both purchased from BioSciences, Ireland (suppliers for Life Technologies).

\section{Cell culture}

A549 cells were cultured in DMEM (with $2 \mathrm{mM}$ L-glutamine) with $10 \%$ foetal bovine serum (FBS) and Calu-1 cells in RPMI with $10 \%$ FBS, both at $37^{\circ} \mathrm{C}$ in a humidified atmosphere containing $5 \% \mathrm{CO}_{2}$ and cells were split every two days to maintain $\sim 60 \%$ confluence. 
For Confocal Laser Scanning Fluorescence Microscopy (CLSM) and Raman micro spectroscopic analysis, cell number was determined using a Beckman Coulter Particle Count and Size Analysis ${ }^{\circledR}$ Z2 Cell Counter.

\section{Cytotoxicity assays:}

$\mathrm{AB}$ and MTT assays were performed in 96 well plates and a total number of $1 \times 10^{5}$ cells were used to seed three plates $\left(4 \times 10^{3}\right.$ cells $\left./ \mathrm{mL}\right)$. After $24 \mathrm{~h}$ incubation, plates were washed with phosphate buffered saline solution (PBS) and DOX was added in a concentration range from $0 \mu \mathrm{M}$ (as a control) to $50 \mu \mathrm{M}$.

$\mathrm{AB}$ and MTT assays were both measured with a Cytotox SpectraMax ${ }^{\circledR} \mathrm{M} 3$ plate reader using Soft Max ${ }^{\circledR}$ Pro6.2.2 software. After $24 \mathrm{~h}$ incubation in DOX, plates were washed with PBS and $100 \mu \mathrm{L}$ of $\mathrm{AB} / \mathrm{MTT}$ solution were added to each well. Plates were then incubated for 3 hours and AB fluorescence and MTT absorbance were measured in the plate reader using, respectively, 540nm excitation, 595nm emission for $A B$ and $570 \mathrm{~nm}$ for MTT. All cytotoxicity assays were made in triplicate and repeated three times and viability data was fitted by a four parameter Hill equation analysis using SigmaPlot 10.0, to yield values of the mean inhibitory concentration, $\mathrm{IC}_{50}$.

\section{Confocal Laser Scanning Fluorescence Microscopy:}

Approximately $1 \times 10^{4}$ cells were allowed to attach on uncoated glass bottom Petri dishes (MatTek Corporation, USA) for two hours, after which they were covered with cell culture medium. After $24 \mathrm{~h}$ incubation, the medium was removed and samples were rinsed twice with sterile PBS, new fresh medium containing DOX corresponding to the median inhibitory concentration, $\mathrm{IC}_{50}$, determined by cytotoxicity assays, was added and cells were incubated for a further $24 \mathrm{~h}$. After incubation, old medium was removed and $2 \mathrm{~mL}$ of Nucred ${ }^{\circledR}$ solution in medium was added and, after 15 to 30 min incubation, samples were rinsed twice with sterile PBS, fixed in formalin $(4 \%, 15 \mathrm{mn})$ and kept in PBS for imaging. Control samples without exposure to DOX were also prepared in parallel, and incubated for $24 \mathrm{~h}$.

CLSM images were recorded using an inverted Zeiss LSM 510 confocal laser scanning microscope equipped with a x60 oil immersion objective. DOX fluorescence was excited with an argon ion laser at $488 \mathrm{~nm}$, and the emission was collected at $530 \mathrm{~nm}$, while Nucred ${ }^{\circledR}$ excitation and emission were respectively measured using 633 and $690 \mathrm{~nm}$. 


\section{Flow Cytometry:}

Cells ( $3 \times 10^{4} /$ flasks) were cultured in T25 flasks over $24 \mathrm{~h}$, and then exposed to a range of DOX concentration (from $0.25 \mathrm{x} \mathrm{IC}_{50}$ to $3.5 \mathrm{x} \quad \mathrm{IC}_{50}$ ). After $24 \mathrm{~h}$ incubation, cells were trypsinised and centrifuged in $5 \mathrm{~mL}$ fresh medium at $4^{\circ} \mathrm{C}$ and $1100 \mathrm{rpm}$ for $5 \mathrm{~min}$, whereupon, they were re-suspended with $1 \mathrm{~mL}$ ice cold Dulbecco's Phosphate-Buffered Saline (DPBS) buffer and centrifuged at $4^{\circ} \mathrm{C}$ and $2500 \mathrm{rpm}$ for $5 \mathrm{~min}$.

Cells were re-suspended in $750 \mu \mathrm{L}$ ice cold DPBS buffer and transferred to Eppendorf tubes to which $250 \mu \mathrm{L}$ of fixation buffer were added. After $30 \mathrm{~min}$ incubation at $4^{\circ} \mathrm{C}$, the fixed cells were washed twice in perm/wash buffer, centrifuged $\left(2500 \mathrm{Rpm}\right.$ for $5 \mathrm{mn}$ at $\left.4^{\circ} \mathrm{C}\right)$ and then gently re-suspended in $50 \mu \mathrm{L}$ perm/wash buffer, after which $20 \mu \mathrm{L}$ of the antibody were added and the cells were incubated for $60 \mathrm{~min}$ in the dark at $4^{\circ} \mathrm{C}$. The cells were then washed twice in perm/wash buffer, centrifuged $\left(2500 \mathrm{Rpm}\right.$ for $5 \mathrm{mn}$ at $\left.4^{\circ} \mathrm{C}\right)$ to remove unbound antibody and finally re-suspended in $1 \mathrm{~mL}$ stain buffer. 10,000 cells were analysed by Flow Cytometry using a BD Biosciences Accuri C6 Flow Cytometer (Becton Dickinson, Oxford, UK). The Accuri Flow cytometry software was used for the analysis of flow cytometry samples and data processing.

\section{Reactive oxygen species (ROS) expression:}

Carboxy-H2DCFDA dye was employed for the detection and quantification of ROS production in the intracellular environment. A solution at $10 \mu \mathrm{M}$ of Carboxy-H2DCFDA was made up in PBS and added to the cells for $1 \mathrm{hr}$ incubation. After incubation, cells were washed three times with PBS, then exposed to DOX for $24 \mathrm{hrs}$. Fluorescence was measured in the plate reader using $488 \mathrm{~nm}$ excitation and $535 \mathrm{~nm}$ emission.

Negative controls, consisting of healthy cells, untreated with DOX, analysed with or without Carboxy-H2DCFDA and DOX treated cells analysed without Carboxy-H2DCFDA, as well as positive controls of healthy cells exposed to a solution of hydrogen peroxide at $1 \mu \mathrm{M}$, were prepared in parallel.

\section{Raman micro spectroscopy:}

Cells ( 1x 10\% /window) were seeded and incubated on $\mathrm{CaF}_{2}$ windows (Crystan Ltd, UK) for $24 \mathrm{~h}$ for both control and exposure to DOX. Medium was then removed and samples were rinsed twice with sterile PBS and covered with $\mathrm{DOX}$ at the $\mathrm{IC}_{50}$. After $24 \mathrm{~h}$ incubation, cells were washed twice with sterile PBS and fixed in formalin $(4 \%, 15 \mathrm{~min})$. 
A Horiba Jobin-Yvon LabRAM HR800 spectrometer with a $785 \mathrm{~nm}, 300 \mathrm{~mW}$ diode laser as source (100mW at the sample), Peltier cooled 16-bit CCD, 300 lines $/ \mathrm{mm}$ grating and $100 \mu \mathrm{m}$ confocal hole, was used to record spectra from the two cell lines, in the range from $400 \mathrm{~cm}^{-1}$ to $1800 \mathrm{~cm}^{-1}$ using a x100 objective (LCPlanN, Olympus N.A. 0,85)), in dry conditions from three cell locations: cytoplasm, nucleus and nucleolus, for 30s two times , to finally produce a data set of 30 points per cell location (one spectrum from each cell compartment per cell) for each control and exposure to DOX, over a total of 120 different cells.

\section{Data analysis:}

Raman spectral pre-processing and analysis were performed in Matlab 2013 using algorithms developed in house. Prior to analysis, spectra were smoothed (Savitsky-Golay filter 5th order, 7 points), vector normalised, baseline corrected (fifth order polynomial) and background and DOX spectral features were subtracted using a non-negatively constrained least squares (NCLS) algorithm. [43]

After pre-processing, principal components analysis (PCA) was employed as an unsupervised multivariate approach to analyse data and the effects of doxorubicin in each cell localisation and in each cell line. The order of the PCs denotes their importance in the dataset, whereby PC1 describes the highest amount of variation. [44]

Independent component analysis (ICA) was also employed as an extension to PCA. ICA is an unsupervised statistical technique able to identify latent variables called independent components. In case of Raman micro spectroscopy, ICA can be used to identify spectral contributions such as those from substrate, using the same number of ICs as PCs, which can then be removed or studied in their own right. [45, 46]

\section{Results and discussion:}

\section{Cytotoxicity assays:}

A.

B. 

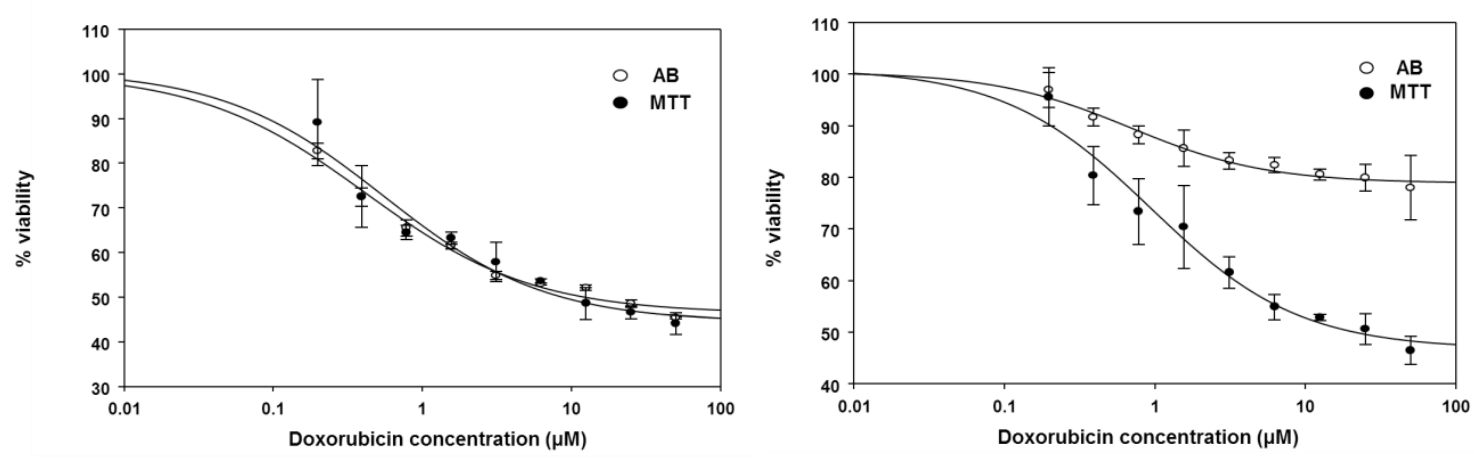

Figure 1: AB and MTT 24 hrs in vitro dose dependent cytotoxicity assays of DOX A. A549 and B. Calu-1. Viability is expressed as \% compared to control, and the error bars indicate the standard deviation of six independent replicate measurements

Figure 1 shows the dose dependant cytotoxicity of DOX after 24hrs exposure, for both cell lines, A549 and Calu-1, according to the AB and MTT in vitro cytotoxicity assays. Viability is expressed as \% compared to control (non-exposed healthy cells), and the error bars indicate the standard deviation of six independent replicate measurements.

For both in vitro assays, a partial loss of cell population viability is observed. However, whereas the AB and MTT for the A549 cell line and the MTT assay for the Calu-1 cell line show similar responses, the $\mathrm{AB}$ assay is relatively insensitive to the Calu- 1 exposure. The differences in the responses between $\mathrm{AB}$ and MTT in the two cell lines, as demonstrated by Figure 1, suggest different sensitivities and/or resistances of the respective cell-lines to the drug, and should be analysed in terms of the mode of response of the assays.

The MTT test is a colorimetric assay that measures the reduction of yellow 3-(4, 5dimethythiazol-2-yl)-2, 5-diphenyl tetrazolium bromide (MTT) by mitochondrial succinate dehydrogenase into purple formazan crystals, insoluble in aqueous solution. [47, 48] Succinate dehydrogenase or succinate-coenzyme Q reductase (SQR) or respiratory Complex II is an enzyme complex, bound to the inner mitochondrial membrane of mammalian mitochondria and many bacterial cells. It is the only enzyme that participates in both the citric acid cycle and the electron transport chain, so the MTT assay is the reflection of mitochondrial activity. Alamar blue (AB), on the other hand, is a water-soluble dye and one of the most highly used cytotoxicity assays for in vitro quantification of the cell viability. [49] When added to cell cultures, the active dye, resazurin or 7-hydroxy-10-oxidophenoxazin-10ium-3-one, diffuses into the cytosol and acts as an intermediate electron acceptor allowing the oxidised blue non-fluorescent form to be reduced by both mitochondrial and cytosolic 
enzyme activity to the fluorescent pink one which is easily measured by its absorption or fluorescence. [47, 48, 50]

Its response is thus considered the expression of general cellular metabolism. Therefore, although reduced conversion compared to controls is used as a measure of reduced cellular viability for both $\mathrm{AB}$ and MTT assays; the MTT response is more specifically sensitive to mitochondrial enzymes while $\mathrm{AB}$ is related to both mitochondrial and cytosolic activities.

As illustrated by Figure 2, A549 cells and Calu-1 exhibit somewhat different $\mathrm{IC}_{50}$ values, as measured using the MTT cytotoxicity assay, determined to be $0.55 \pm 0.16 \mu \mathrm{M}$ and $0.90 \pm 0.24$ $\mu \mathrm{M}$ for the A549 and Calu-1 cell lines respectively. The most notable differences observed, however, are in the $\mathrm{AB}$ cytotoxicity profiles, which are characterised by $\mathrm{IC}_{50}$ values of 0.42 $\pm 0.06 \mu \mathrm{M}$ and $0.69 \pm 0.13 \mu \mathrm{M}$ for the A549 and Calu-1 cell lines respectively. For the same DOX dosage, although similar changes in mitochondrial activity (as recorded by the MTT assay) and the overall cellular metabolism (as recorded by the AB assay) are observed for the A549 cell line, the overall dose dependent change in cellular metabolism, as recorded by the $\mathrm{AB}$ assay, is considerably less in the Calu-1 cell line.

The differing cytotoxic profiles for the two cell lines, is consistent with the contribution of multiple mechanisms to the toxic response, and a greater intrinsic resistance of the Calu-1 cell line to one or more of these mechanisms. The underlying mechanisms will be studied in more detail in the following sections. Since cells will be analysed after $24 \mathrm{~h}$ exposure, the $\mathrm{IC}_{50}$ determined using the MTT assay was used for the rest of the study, for both cell lines.

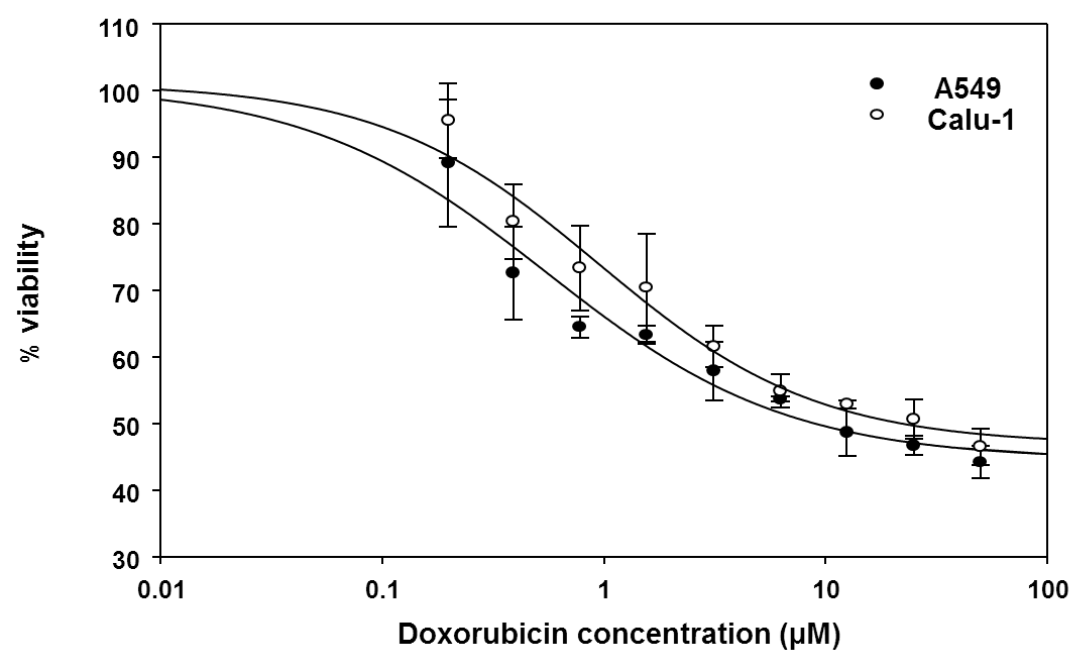

Figure 2: MTT 24 hrs dose dependent cytotoxicity of DOX to A549 and Calu-1 


\section{Confocal Laser Scanning Fluorescence Microscopy:}

A.

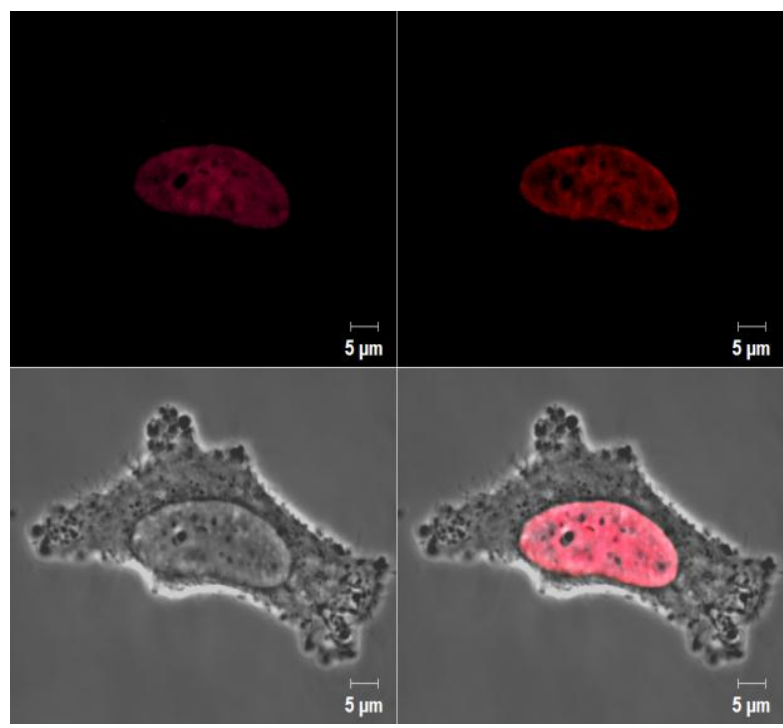

B.

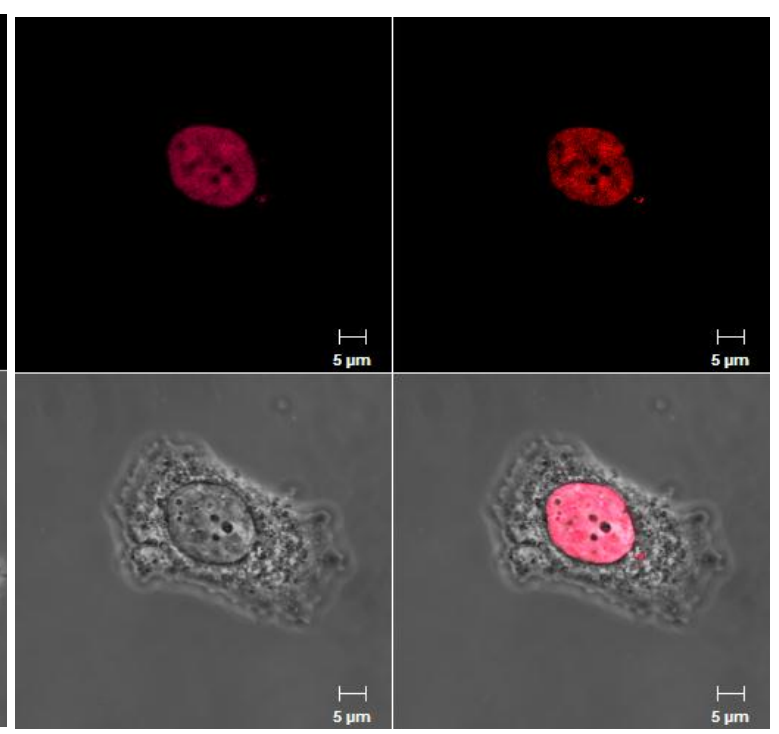

Figure 3: Confocal Laser Scanning Fluorescence images of A. A549 and B. Calu-1 after 24h DOX exposure and Nucred $^{\circledR}$ staining confirming the DOX nuclear localisation.

CLSM was employed to visualise the DOX intracellular internalisation and localisation in both cell lines. Figure 3 illustrates the images for A549 and Calu-1 cells after 24hr DOX exposure, at the respective MTT IC $_{50}$ concentration for each cell line, and Nucred ${ }^{\circledR}$ staining. DOX is predominantly localised on the nuclear area and, for both cell lines after exposure, cells appear smaller in size and round or oval in shape and exhibit noticeable nucleoli fragmentation, known as karyorrhexis, and membrane blebbing. The cytoplasm is more tightly packed as a result of cellular shrinkage. All these morphological changes indicate that cells are going under apoptosis. [28, 29, 51-54] 
Using ImageJ software, after fluorescence background subtraction, the mean fluorescence intensity of the nuclear area was measured for 10 cells for each cell line. The average DOX fluorescence intensity was determined to be, respectively $644 \pm 29$ AU for the A549 cell line and $725 \pm 11$ AU for Calu-1, indicating that a larger amount of DOX is present in the Calu-1 nucleus, despite the fact that the $\mathrm{IC}_{50}$ value for Calu-1 is almost twice that of $\mathrm{A} 549$ and the global nuclear volume is slightly higher for A549 than Calu-1. [42]

\section{Flow Cytometry and bcl-2 expression:}

Bcl-2 is an intracellular nuclear membrane anti apoptotic protein synthetised in direct response to DNA damage, in this case due to intercalation of DOX. As shown in Figure 4, a similar expression profile of up regulation followed by down regulation of the bcl-2 protein, as a function of DOX concentration, was observed for the two cell lines and this expression profile has been reported to be responsible for the resistance to apoptosis up to certain doses, above which DNA damage becomes prominent and bcl-2 levels decrease as cells enter apoptosis.[55]

A.

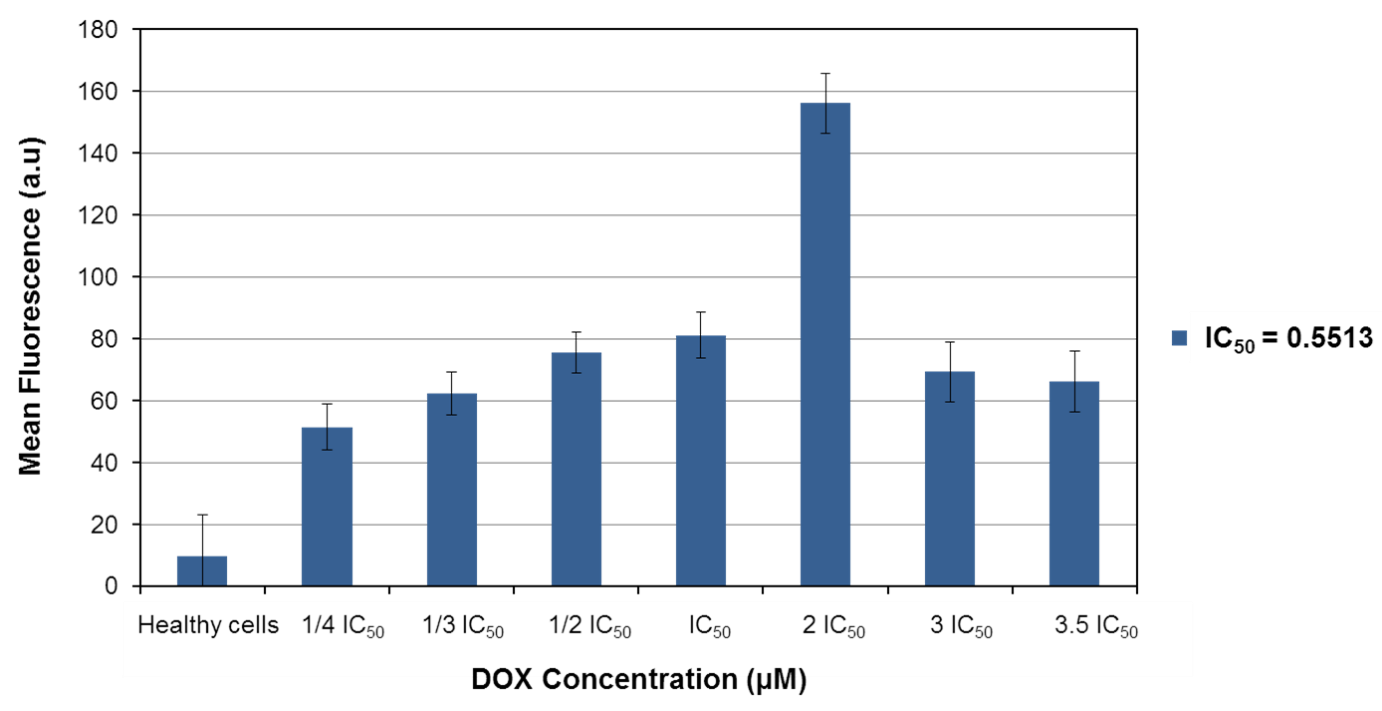

B. 


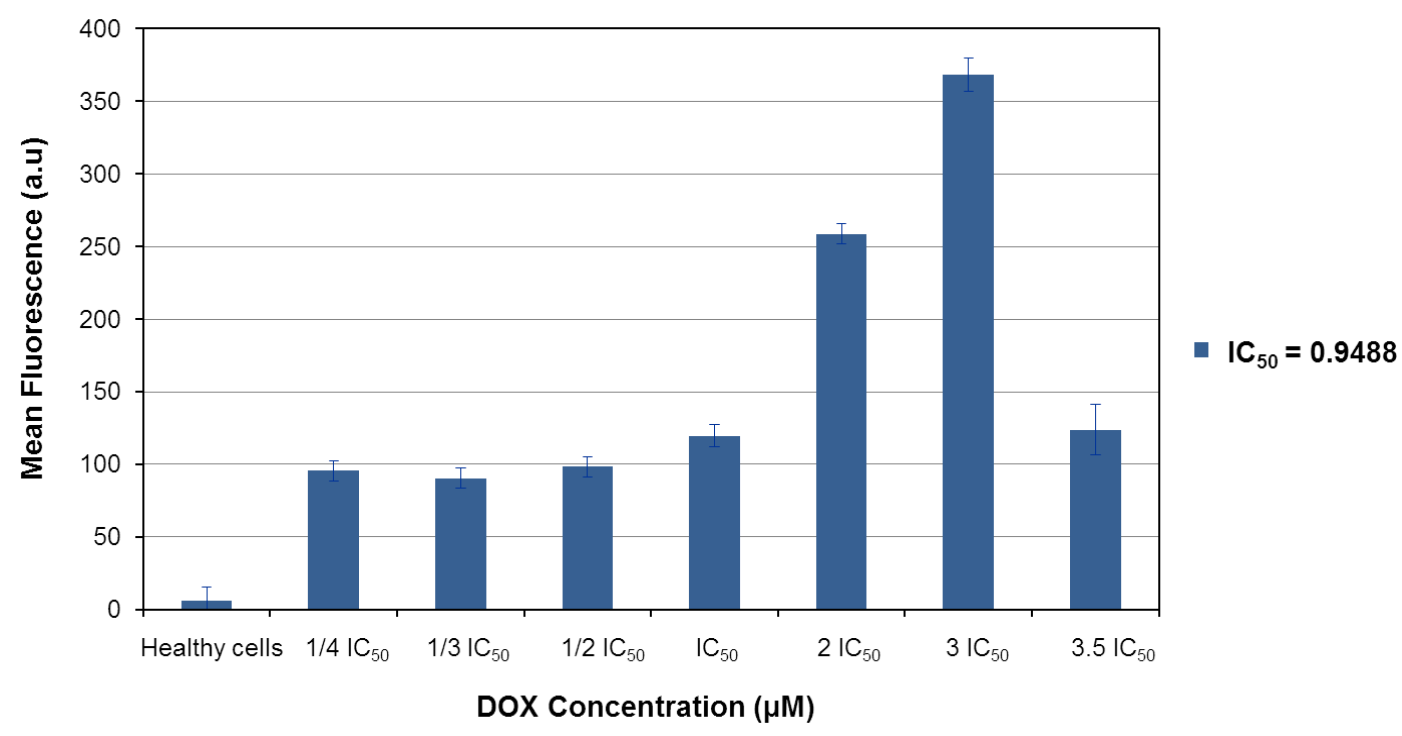

Figure 4: Expression level of bcl-2 due to DOX exposure and control healthy cells for $\mathbf{A}$. A549 and B. Calu-1 determined by Flow Cytometry.

The differences between the two bcl-2 expression profiles for each cell line, as a function of MTT $\mathrm{IC}_{50}$ are manifest in the maximum level of bcl-2, and the dose at which this is reached. It is notable that the bcl-2 level in Calu-1 cells is consistently higher over the dose range than A549, with a maximum expression at $2 \mathrm{IC}_{50}$ for $\mathrm{A} 549(1.1 \mu \mathrm{M})$ and $3 \mathrm{IC}_{50}$ for Calu-1 $(2.7 \mu \mathrm{M})$.

\section{ROS production monitored by DCFDA:}

In addition to the mode of action of DNA intercalation, internalised DOX can also lead to the generation of intracellular ROS in the cytosol by redox activation in the presence of NADPH, forming a quinone radical via one electron transfer and generating peroxide and superoxide, [56, 57] resulting in DNA, mitochondrial and cell membrane damage by oxidation, responsible for its most significant chronic side effect, cardiotoxicity. [58, 59]

ROS were measured by the DCFDA dye, a highly fluorescent compound in presence of ROS which can be detected by fluorescence. As detailed in Table 1, and illustrated schematically in Figure 5, significantly higher ROS levels are present in Calu-1 cells than A549 (Test (DOX+DCFDA)), after $24 \mathrm{hr}$ exposure to the DOX $\mathrm{IC}_{50}$ concentration, as measured by the MTT assay. In fact, Calu-1 has higher ROS levels compared to A549 even without any DOX exposure and this expression becomes even higher after DOX exposure, emphasising the difference between the two cell lines. ROS are usually generated through a cascade of reactions resulting from the distinct oxidation status of $\mathrm{O}_{2}$, including its radical forms, such as 
the superoxide radical, and non-radical forms such as hydrogen peroxide, $\mathrm{H}_{2} \mathrm{O}_{2}$. [60] Cancer cells have a high level of ROS, recognized to be signalling molecules in various biological processes, eliciting proliferation, genomic instability and inflammation[61] but a considerable increase of ROS level induces damage and promotes apoptosis. [59, 61] Although the relationship between DNA mutations, ROS generation, and drug sensitivity remains unclear, the ROS mediated apoptosis mechanism appears to be activated in the Calu-1 cell line to a significantly greater extent than in A549.

Table 1: ROS production in A. A549 cell line and B. Calu-1 cell line, negative controls using healthy cells and no DCFDA, exposed cells and no DCFDA and healthy cells with DCFDA and $\mathrm{H}_{2} \mathrm{O}_{2} 1 \mu \mathrm{M}$ solution as positive control

A.

\begin{tabular}{|c|c|c|c|c|c|}
\hline & \multicolumn{3}{|c|}{ Negative controls (Arb.Units) } & \multirow{2}{*}{$\begin{array}{l}\text { Positive control } \\
\left(\text { Cells }+\mathrm{H}_{2} \mathrm{O}_{2}+\right. \\
\text { DCFDA) } \\
\text { (Arb. Units) }\end{array}$} & \multirow{2}{*}{$\begin{array}{l}\text { Test } \\
\text { (DOX+DCFDA) } \\
\text { (Arb. Units) }\end{array}$} \\
\hline & $\begin{array}{l}\text { Healthy } \\
\text { cells +PBS } \\
\text { (no } \\
\text { DCFDA) }\end{array}$ & $\begin{array}{l}\mathrm{DOX}+\mathrm{PBS} \\
\text { (no } \\
\text { DCFDA) }\end{array}$ & $\begin{array}{l}\text { Negative } \\
\text { control } \\
\text { (healthy cells } \\
\text { +DCFDA) }\end{array}$ & & \\
\hline Average & 70.85706 & 254.6403 & 80.57879 & 190.1014 & 279.9507 \\
\hline STD & 10.88444 & 12.0606 & 6.892106 & 28.31797 & 25.60829 \\
\hline Ave $\%$ & 87.93512 & 316.014 & 100 & 235.9199 & 347.4248 \\
\hline STD \% & 13.50783 & 14.96746 & 8.55325 & 35.14321 & 31.78044 \\
\hline
\end{tabular}

B.

\begin{tabular}{|c|c|c|c|c|c|}
\hline & \multicolumn{3}{|c|}{ Negative controls } & \multirow{2}{*}{$\begin{array}{l}\text { Positive } \\
\text { control } \\
\left(\text { Cells }+\mathrm{H}_{2} \mathrm{O}_{2}+\right. \\
\text { DCFDA })\end{array}$} & \multirow{2}{*}{$\begin{array}{l}\text { Test } \\
\text { (DOX+DCFDA) }\end{array}$} \\
\hline & $\begin{array}{l}\text { Healthy } \\
\text { cells +PBS } \\
\text { (no } \\
\text { DCFDA) }\end{array}$ & $\begin{array}{l}\mathrm{DOX}+\mathrm{PBS} \\
\text { (no } \\
\text { DCFDA) }\end{array}$ & $\begin{array}{l}\text { Negative } \\
\text { control } \\
\text { (healthy cells } \\
\text { +DCFDA) }\end{array}$ & & \\
\hline Average & 47.589 & 312.8539 & 309.0865 & 356.7716 & 1214.652 \\
\hline STD & 10.91059 & 23.91193 & 21.34131 & 24.93965 & 63.87997 \\
\hline Ave \% & 15.39666 & 101.2189 & 100 & 115.4277 & 392.9813 \\
\hline STD \% & 3.529947 & 7.736324 & 6.90464 & 8.068825 & 20.66734 \\
\hline
\end{tabular}




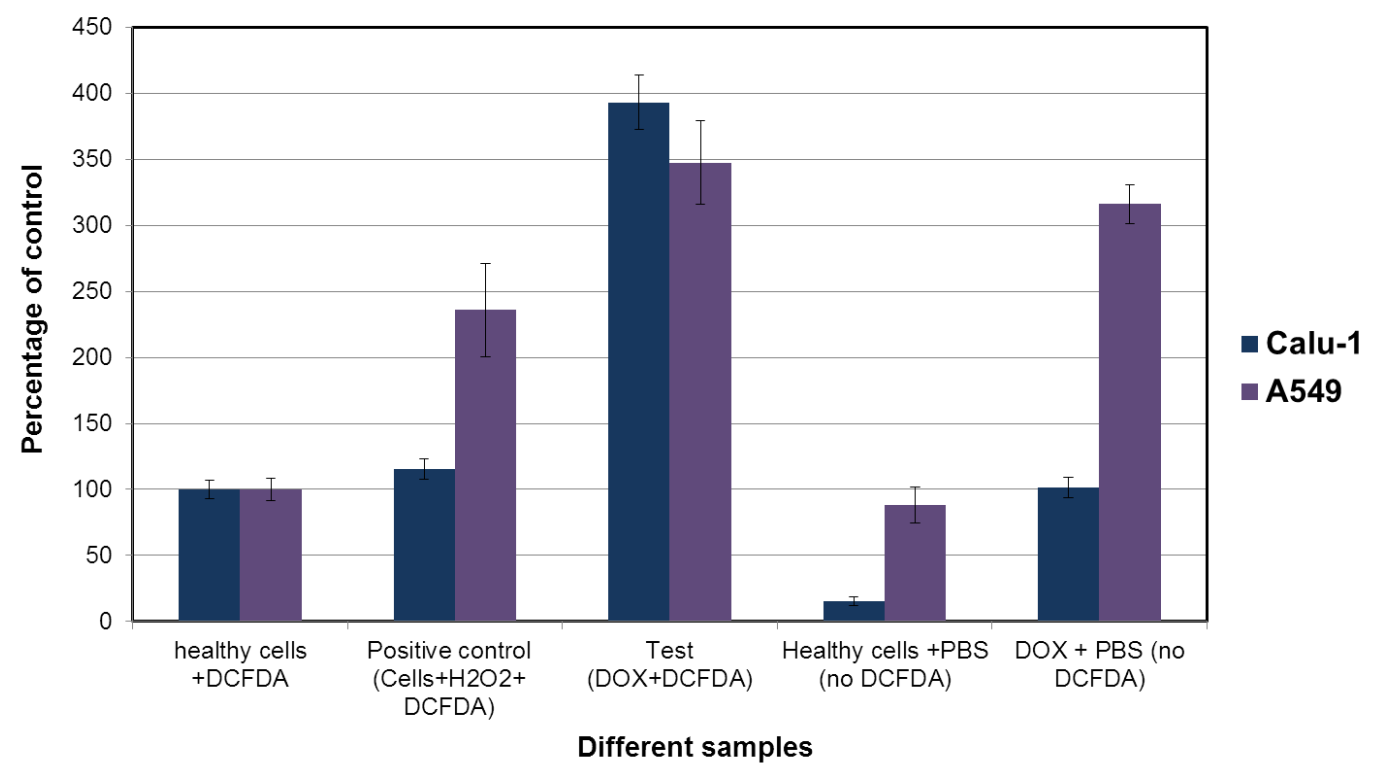

Figure 5: Reactive oxygen species generation expressed on percentage of control for Calu-1 and A549 cell lines.

\section{Raman micro spectroscopy:}

Raman spectrosopy has previously demonstrated that A549 and Calu-1 cells are distinguishable, based on the spectral profile of their nucleoli. [42] Furthermore, it has previously been employed to profile the interactions of DOX within the nuclear and nucleolar regions of A549 cells. [14] In order to further elucidate the subcellular differences of the responses and potential resistance mechanisms of the A549 and Calu-1 cell lines to DOX exposure, Raman spectra, for both A549 and Calu-1 cells, were taken from the three cellular compartments after $24 \mathrm{hrs}$ exposure to the MTT $\mathrm{IC}_{50}$ concentration of DOX corresponding to each cell line. For PCA analysis, figures corresponding to spectral differentiation according to PC1 and PC2 were plotted and, for clarity, the corresponding loadings are off set, and the dashed horizontal line in all cases indicating zero loading.

Figure 6 shows the mean spectra of nucleolus, nucleus and cytoplasm for Calu-1 cell lines along with the spectrum of DOX powder dissolved in sterile water. Nucleolar size for both control cell lines is of the order of $2-4 \mu \mathrm{m}$, although it reduces to $\sim 1-2 \mu \mathrm{m}$ due to DOX exposure inducing fragmentation (Figure 3) [ref]. Nevertheless, it remains larger than the Raman laser spot $(1 \mu \mathrm{m})$, allowing Raman spectra acquisition specifically from the nucleoli. 


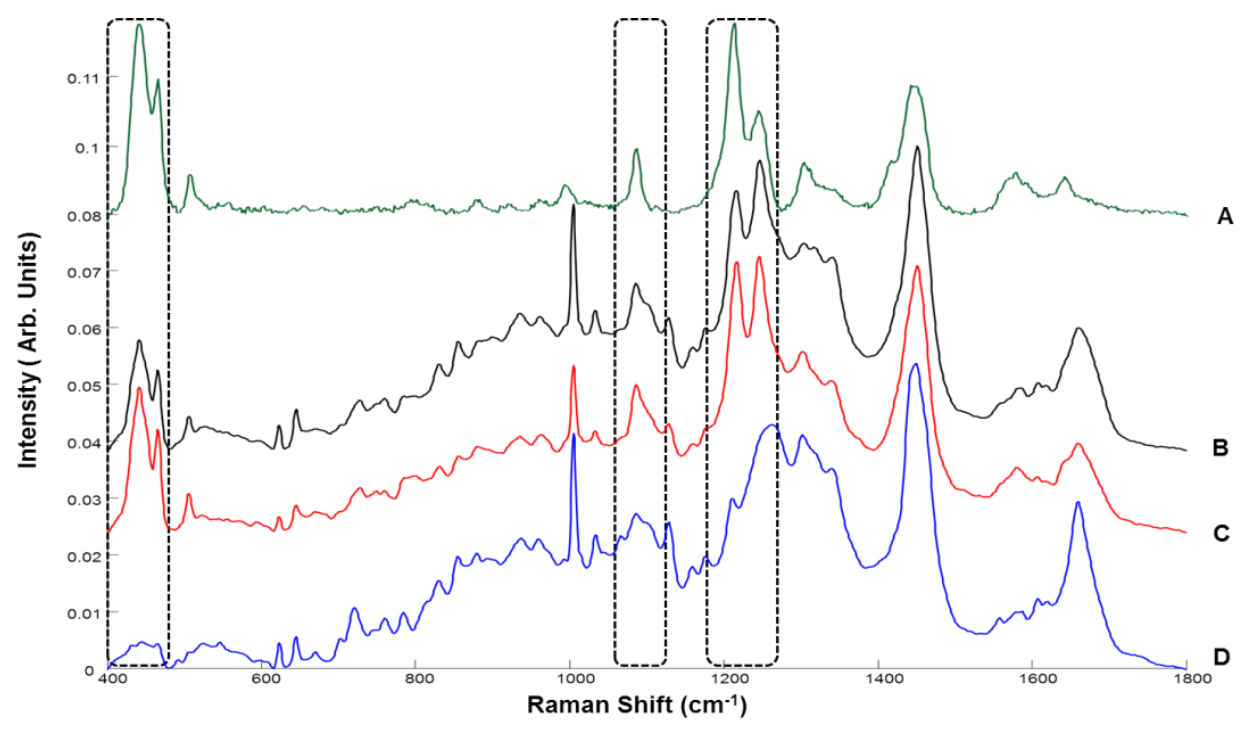

Figure 6: Spectrum of Doxorubicin (A) and mean spectra of Nucleolus (B), Nucleus (C) and Cytoplasm (D) of the Calu-1 cell line, highlighted regions indicating discriminating Doxorubicin features.

As shown in previous study of the A549 cell line by Farhane et al. [14], and as seen in Figure 6 for the Calu-1 cell line, obvious DOX features (indicated by highlighted regions) at 440 and $465 \mathrm{~cm}^{-1}$ respectively $\mathrm{C}-\mathrm{C}-\mathrm{O}$ and $\mathrm{C}-\mathrm{O}$ and 1085,1215 and $1245 \mathrm{~cm}^{-1}$ related to $\mathrm{C}-\mathrm{O}, \mathrm{C}-\mathrm{O}-$ $\mathrm{H}$ and $\mathrm{C}-\mathrm{H}$ are observed in the nucleolar and nuclear region for both cell lines, confirming the predominant localisation of the drug in these regions.

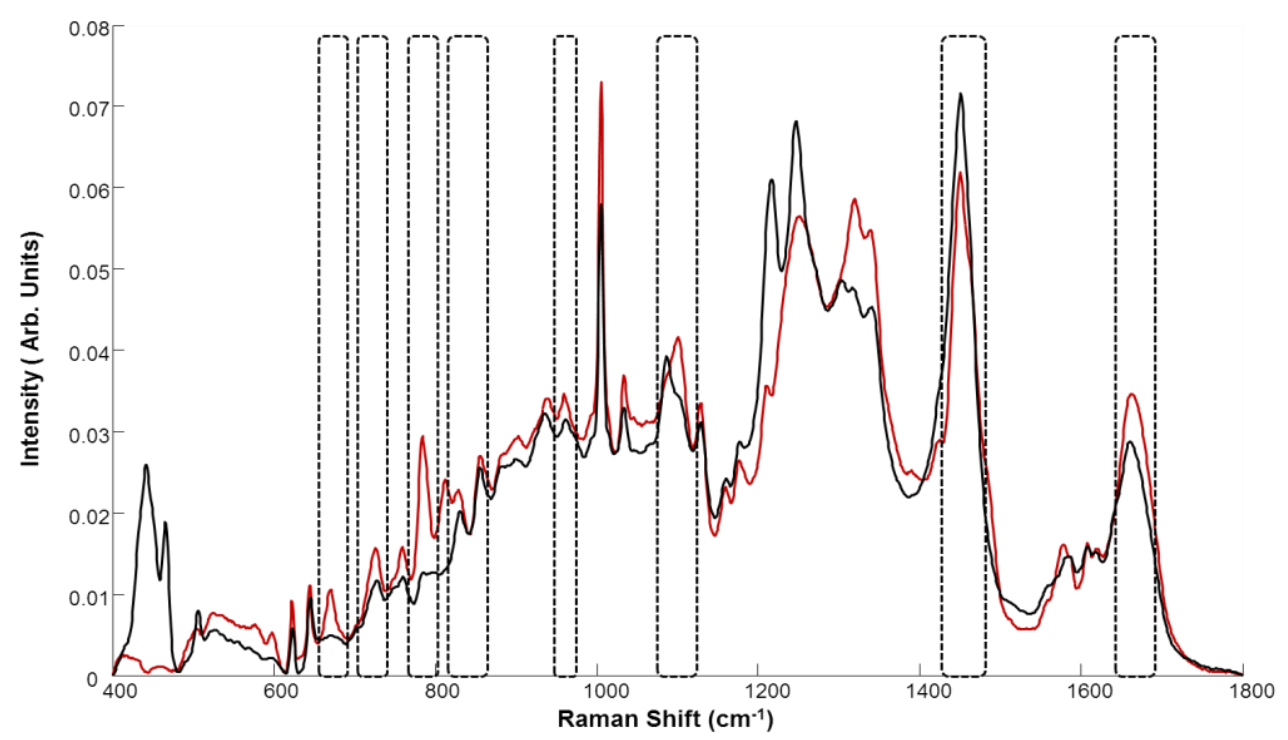

Figure 7: Mean spectra of the nucleoli of Calu-1 cells highlighting the spectroscopic changes after DOX exposure; control (brown) and after DOX exposure (black) 
Additionally, in the mean spectra of the nucleolus of Calu-1, before and after DOX exposure, an evident diminishment of peaks at 847 and $960 \mathrm{~cm}^{-1}$ can be seen (highlighted in Figure 7), indicating a modification of ribose phosphate backbone due to DOX intercalation. Moreover, obvious decreases of DNA peaks at $669,728,782$ and $830 \mathrm{~cm}^{-1}$ in the spectra of the nucleolus of treated cells compared to non-treated ones are observed, due to DOX-DNA interactions inducing DNA synthesis interruption [57] and changes in DNA conformation (decrease of DNA B form) [62] inducing early cell apoptosis. [54, 63] (Similar results were found for nuclear spectra, data not shown). In addition to the decrease in DNA peaks, a shift towards lower wavenumbers is observed for the peak at $1095 \mathrm{~cm}^{-1}$, corresponding to O-P-O stretching, which indicates that DOX is also able to bind to DNA externally. [62] Besides the effects on DNA related spectral features, it appears that proteins and lipids are also affected, as evidenced by the decrease of their corresponding peaks, for example, respectively at 1450 and $1665 \mathrm{~cm}^{-1}$. The peak at $1450 \mathrm{~cm}^{-1}$ is influenced by DOX peak proximity but, after DOX subtraction, it can be clearly seen that this peak is diminished (data not shown). [64]

A more detailed analysis of the changes in the spectral features as a result of DOX exposure and comparison between the responses of the two cell lines is facilitated by PCA. Figure 8, showing PCA of nucleolar, nuclear and cytoplasmic regions, for A549 and Calu-1 cells after exposure to DOX, exhibits a separation between the three cellular compartments and the corresponding loading of PC1, differentiating the combined nuclear region from the cytoplasmic one, is dominated on the positive side by DOX features, confirming once again its predominantly nuclear and nucleolar subcellular localisation, for both cell lines. The negative side is dominated by lipidic features at $1450 \mathrm{~cm}^{-1}\left(\mathrm{CH}_{2}\right.$ deformation) and $1661 \mathrm{~cm}^{-1}$ (Lipids $\mathrm{C}=\mathrm{C}$ stretching), corresponding to biochemical changes in the cytoplasmic region. $[13,65,66]$ 
A.
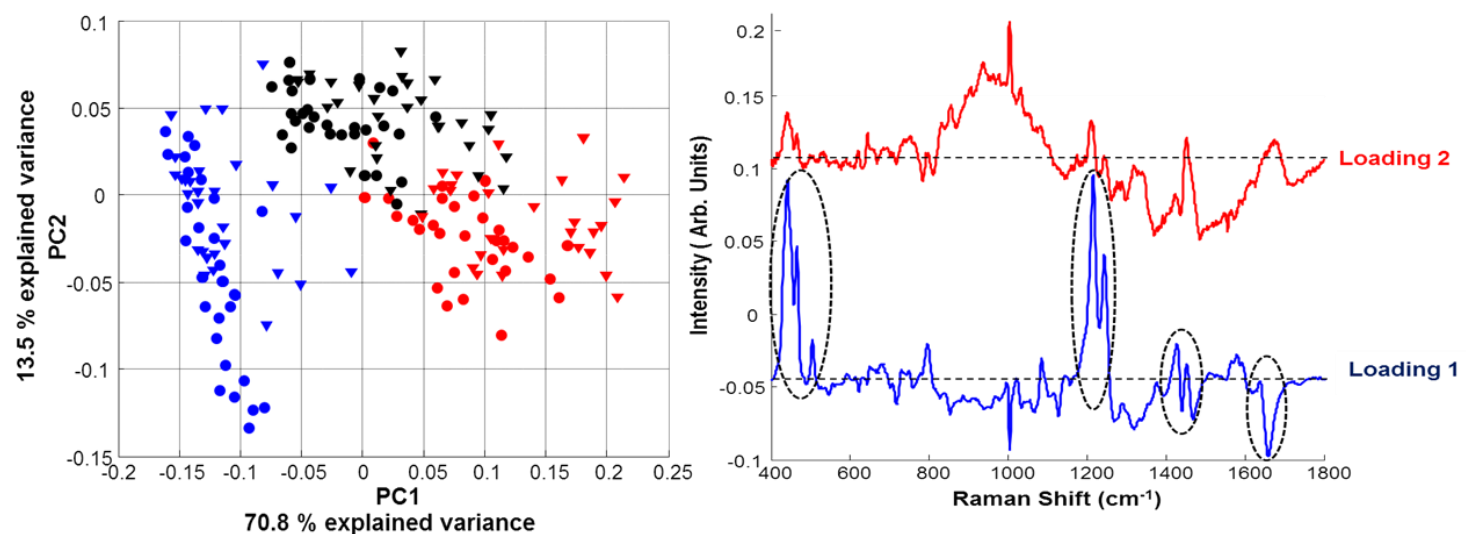

B.
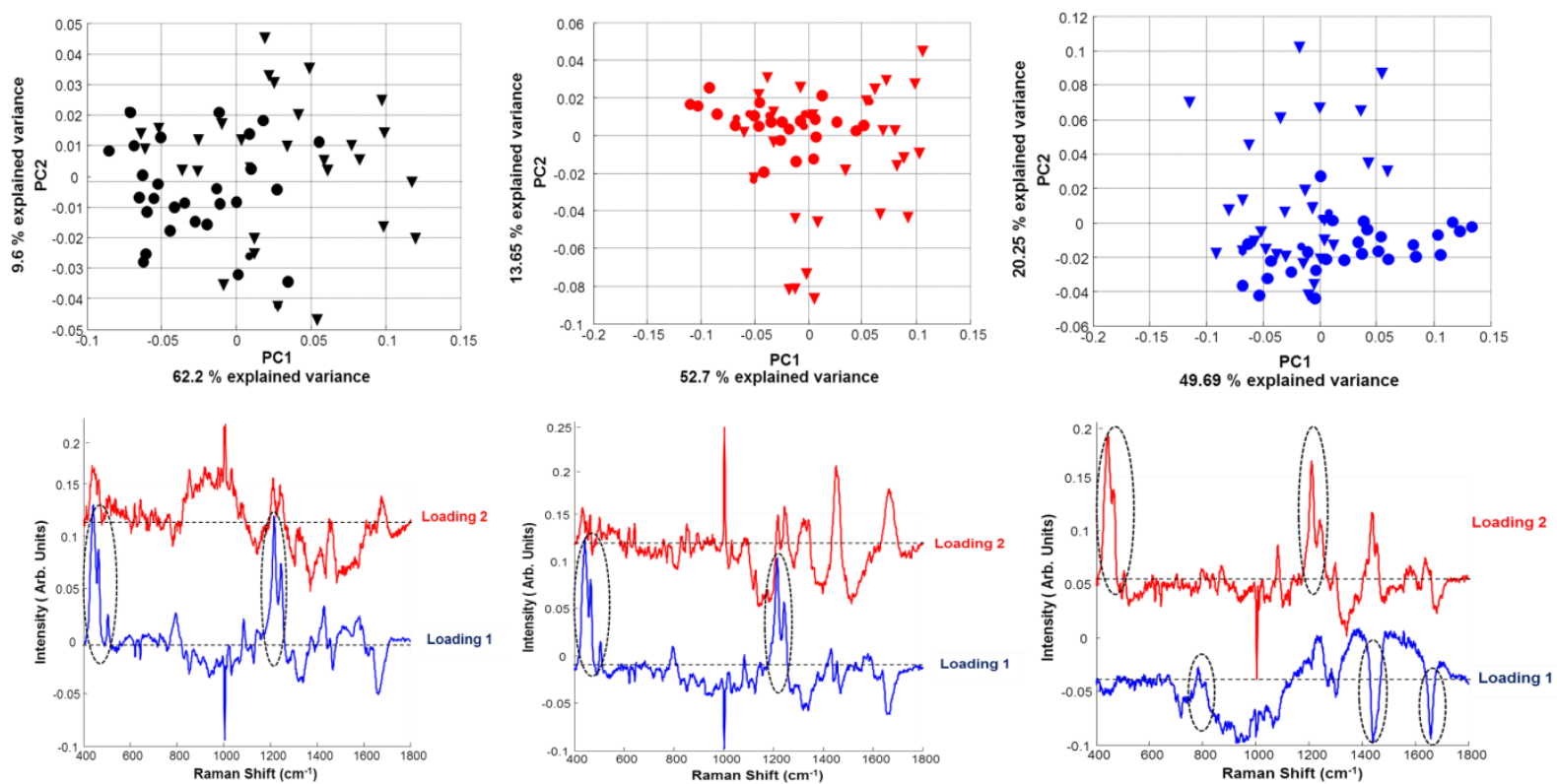

Figure 8: PCA of nucleolar, nuclear and cytoplasmic regions of A. A549 and Calu-1 with corresponding loadings of PC1 and PC2 B. PCA of each cell localisation for A549 and Calu1 and the corresponding loadings of PC1 and PC2

Nucleolus • Nucleus • Cytoplasm • A549 cell line

Nucleolus $\nabla$ Nucleus $\nabla$ Cytoplasm $\nabla$ Calu-1 cell line

A pairwise PCA of the three cellular regions was performed, and it is notable in Figure 8B, that PC1 clearly differentiates the nucleolar and nuclear regions between the two cell lines and the corresponding loading of PC1 clearly exhibits positive DOX features, indicating that there is more DOX in Calu-1 than in A549 cells, supporting the ImageJ analysis of the CLSM 
images. Negatives features at 1320 and $1450 \mathrm{~cm}^{-1}\left(\mathrm{CH}_{2}\right.$ deformation) and $1661 \mathrm{~cm}^{-1}$ (Lipid $\mathrm{C}=\mathrm{C}$ stretching) are also observed in the loading of $\mathrm{PC} 1$ for nucleolar, nuclear and cytoplasmic areas, indicating that there is higher lipidic content in A549 cells than in Calu-1.
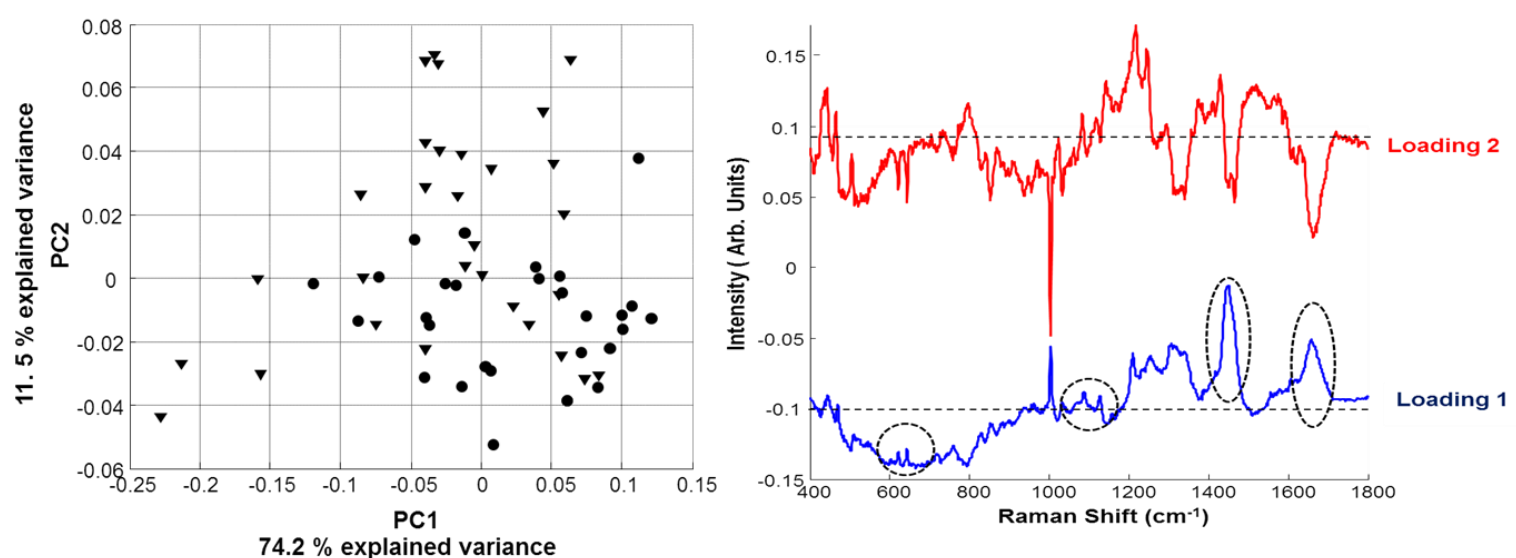

Figure 9: PCA of nucleolar compartment of Calu-1 and A549 after DOX spectral features subtraction and corresponding loadings of PC1 and PC2

Nucleolus • A549 cell line after DOX subtraction

Nucleolus $\nabla$ Calu-1 cell line after DOX subtraction

The differing cellular responses, in the subcellular regions, can be better visualised after subtraction of the DOX spectral signature from the cellular spectra. [14] Figure 9 shows the PCA of the nucleolus of A549 and Calu-1 after subtraction of DOX spectral features. Although the differentiation is not absolute, the A549 data is predominantly distributed with positive loadings of PC1, and vice versa for Calu-1. The loading of PC1 indicates that there is a more pronounced increase in some protein features in Calu-1 cells, than in A549. These include those at $645 \mathrm{~cm}^{-1}$ (C-C twist Tyrosine), $936 \mathrm{~cm}^{-1}$ (C-C stretching), $1176 \mathrm{~cm}^{-1}$ (Tyrosine), $1450 \mathrm{~cm}^{-1}(\mathrm{C}-\mathrm{H})$ and $1665 \mathrm{~cm}^{-1}$ (Amide I). Similar changes are apparent in these protein related features in the mean spectra of Figure 6, although they are less pronounced in the mean spectra of A549. [14]

A further notable difference in the Raman profiles of Calu-1 compared to A549 cells is seen in the cytoplasmic region. Figure 6 reveals traces of DOX features for Calu-1, most apparent in the region from $\sim 400-450 \mathrm{~cm}^{-1}$, which suggests the presence of a small amount of DOX in the cytoplasm, undetectable by CLSM. These are completely absent in the case of A549. [14] The same DOX features are obvious in the loading of PC2, separating the two cytoplasmic regions, in Figure 8B, further indicating the presence of DOX in the cytoplasm of Calu-1 
cells, while it is not detectable in A549. This observation highlights the sensitivity of Raman spectroscopic profiling to even small quantities of drugs inside cells and indicates that the sub-cellular distribution of DOX after $24 \mathrm{hr}$ exposure differs between the two cell lines.

In order, to investigate the DOX mechanism of action in more details, and to support and complement the PCA observations, ICA was performed using three components, as estimated by PCA, explaining the majority of variance, and only the first conponent for each cellular compartment was plotted and off set for clarity.

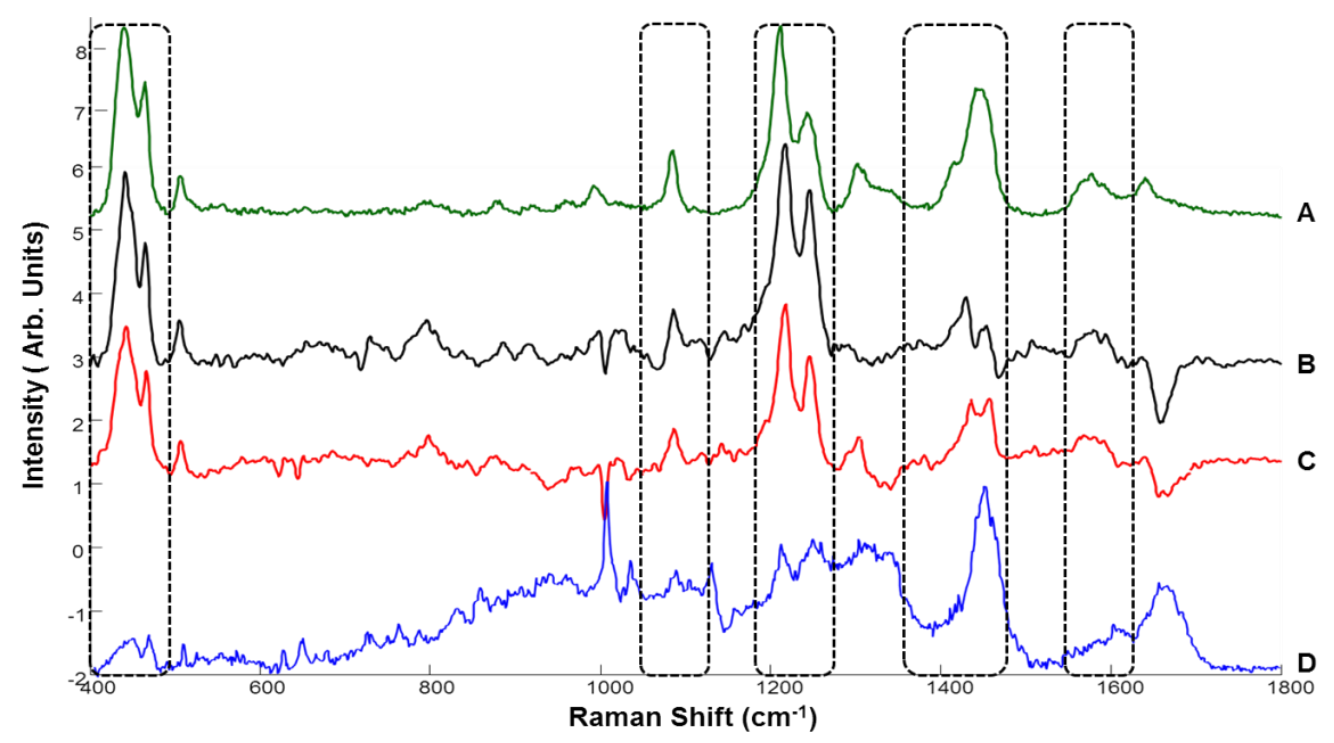

Figure 10: A. DOX spectrum and A549 ICA component B. Nucleolus C. Nucleus and D. Cytoplasm

Figures 10 and 11 represent the ICA signals for the nucleolar, nuclear and cytoplasmic regions, respectively for the A549 and Calu-1 cell lines, plotted with the raw DOX spectrum for comparison. It is notable that the nucleolar and nuclear components exhibit DOX features at $440,465 \mathrm{~cm}^{-1}, 1085,1215$ and $1245 \mathrm{~cm}^{-1}$ for both cell lines, while these features are only strongly observed (Figure 11) in the cytoplasm of Calu-1, confirming the PCA results. 


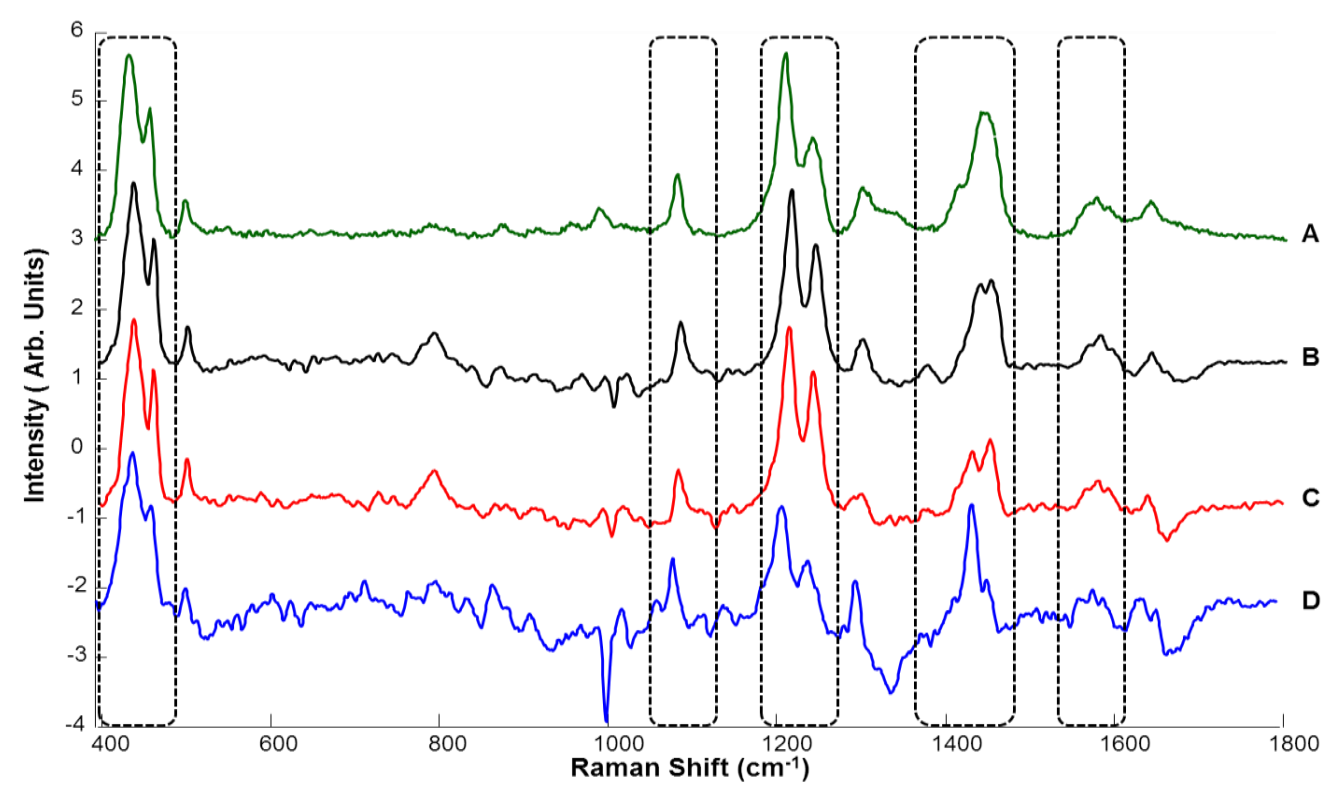

Figure 11: A. DOX spectrum and Calu-1 ICA component B. Nucleolus C. Nucleus and D. Cytoplasm

In both Figure 10 and 11, the peak at $795 \mathrm{~cm}^{-1}$ in the IC for both the nucleolus and nucleus (absent in the cytoplasm) corresponds to nucleic acid and confirms the nucleic DOX intercalation, while the negative peak at $1665 \mathrm{~cm}^{-1}$ represents a decrease in the protein Amide I response, consistent with the analysis of the mean spectrum of nucleolus and nucleus before and after DOX exposure. The IC for both the nucleolus and nucleus also exhibit obvious features at $1430-1456 \mathrm{~cm}^{-1}$. These peaks are not visible in mean spectra, due to the proximity of lipid peaks and are absent in ICA of the control cells before exposure to DOX (data not shown). While these signatures could be attributed to DOX, they also correspond to signatures of Guanine and Cytosine. [67] The increase in these nucleic acid signatures could be due to DOX-DNA intercalation. DOX intercalates preferentially between two adjacent GC bases [20], inducing changes in DNA conformation, damage of the DNA double helix structure and the observed spectral changes may therefore be evidence of DOX intercalation between Guanine and Cytosine bases. There is also a hyperchromic effect observed for the peak at $1376 \mathrm{~cm}^{-1}$ corresponding to Thymine, Adenine, Guanine (ring breathing modes of the DNA/RNA bases). [68-70] 


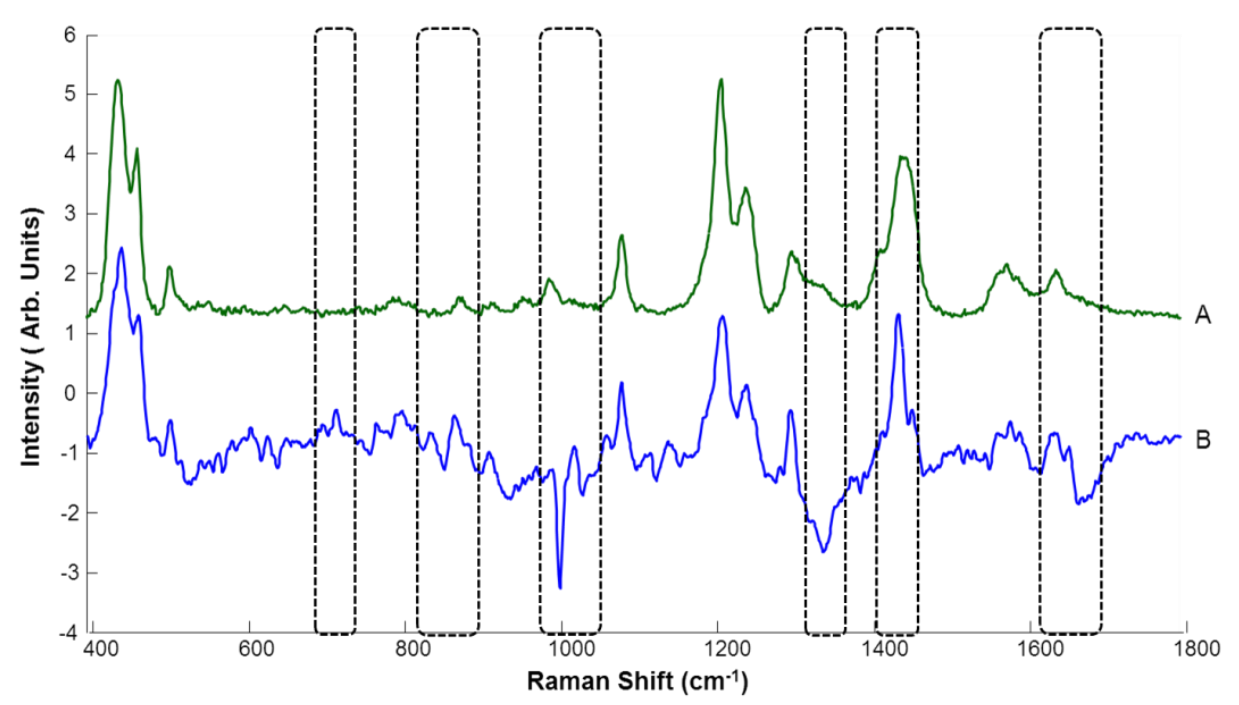

Figure 12: A. Spectrum DOX and B. Cytoplasm Calu-1 cell line ICA component.

In the ICA of the cytoplasm of DOX exposed Calu-1 cells (Figure 12), DOX features are clearly evident, confirming DOX localisation in the cytoplasm. However, the spectral profile of the IC is considerably different than that of pristine DOX, and the IC of the nuclear and nucleolar regions. This is consistent with a metabolisation of the DOX molecules within the cytoplasm, and the resultant cellular interaction is manifest as the spectral features at 720 and $877 \mathrm{~cm}^{-1}$ corresponding to $\mathrm{C}-\mathrm{C}-\mathrm{N}+$ stretching, ones at $1024,1343 \mathrm{~cm}^{-1}$ and $1456 \mathrm{~cm}^{-1}$, related to $\mathrm{C}-\mathrm{H}$ vibrations and $1661 \mathrm{~cm}^{-1}$, corresponding to lipidic $\mathrm{C}=\mathrm{C}$ stretching. [14, 71]

\section{Discussion}

The analysis of the dose dependent cytotoxic response of the two cell lines to DOX exposure, after 24 hrs shows a notably different profile, particularly for the case of the Alamar Blue assay. The results are consistent with an increased resistance of the Calu-1 cell line to the drug, compared to A549. The traditional cytotoxic assays shed little light on the origin of the different cellular responses, in terms of the cellular pharmacokinetics, however. The flow cytometric analysis indicates that DOX exposure elicits significantly higher upregulation of the anti-apoptotic protein bcl-2 in the Calu-1 cell line, while analysis of the induced oxidative stress reveals substantially higher levels of ROS in Calu-1.

DOX is reported to induce cell death by two principle modes of action, and the results are consistent with different relative contributions to the cytotoxic response in the two cell lines. 
DOX is rapidly trafficked to the cell nucleus (and mitochondria), where it binds with the DNA by intercalation, inducing DNA damage and initiating an apoptotic cascade, registered by the MTT assay. The MTT assay registers similar cytotoxicity profiles for the two cell lines, and the somewhat higher $\mathrm{IC}_{50}$ value for Calu-1 is consistent with the observation from CLSM that there is a higher uptake of DOX in the nuclei of Calu-1. The DNA damage in cell nuclei triggers the upregulation of the anti-apoptotic protein bcl-2, which inhibits the apoptotic process. This response is significantly stronger in the Calu-1 cell line, and this greater resistance to apoptosis is consistent with the substantially lower loss of cell viability as registered by the $\mathrm{AB}$ assay. Concomitantly, a significantly higher degree of oxidative stress in the Calu-1 cell line is observable. ROS generation in the cytosol, resulting in DNA damage in the nucleus, is the second reported mode of action of DOX. The process is the result of a complex cascade initiated by the reduction of DOX in the presence of NADPH and, in comparison to the direct interaction of DOX with the nuclear DNA, is a relatively slow process.

The combination of the cytotoxic assays, Flow Cytometry and CLSM can help to understand the underlying mechanisms of the different responses of the two cell lines to DOX exposure, and the apparent higher resistance one to cell death. As a label free, high content analysis technique, Raman spectroscopy can provide similar insights in a single measurement. Notably, Raman spectroscopy gives a clear indication of the presence of DOX and/or its semiquinone metabolite in the cytoplasm of Calu-1 cells, whereas it is not apparent in A549 cells. This observation is indicative of a retarded transport of the drug to the nuclei of Calu-1 cells, and an increased contribution of oxidative stress to the cellular response mechanism. Contained in the spectral changes of the cytoplasm are also signatures of cell damage, characteristic of the response mechanism. In the cell nuclei, DOX exposure produces clear signatures of DNA intercalation, as well as external groove binding, in both cell lines. In the nuclei of Calu-1 cells, there is a significantly higher increase in protein activity, consistent with the upregulation of the cellular anti-apoptotic resistance mechanism.

The results of the Raman micro spectroscopic investigation therefore clearly demonstrate signatures of the interaction of the DOX with the two cell lines, and the mechanisms of cellular response. The differences in response are consistent with the differences observed through the combination of established techniques of cytotoxic assays, flow cytometry and CLSM. 
However, the spectroscopic signatures are obtained in a single, label free measurement. It is noted that the chemotherapeutic agent chosen here, DOX, is a relatively strong Raman scatter, due to is $\pi$-conjugated anthracycline structure, and much is already known about its mechanisms of interaction. Nevertheless, the study serves as a further illustration of the potential of Raman spectroscopy as an in vitro companion diagnostic tool. Although the screening was performed at a single time point, ongoing technological developments such as in nonlinear Raman techniques promise significantly enhanced signals, and therefore reduced sampling times, and ultimately real time monitoring of cellular uptake of drugs and other external agents such as nanoparticles, and the subsequent cellular responses.

\section{Conclusion:}

The study further demonstrates the potential of Raman micro spectroscopy as a high content, label free in vitro tool, not only to localise drugs within cells, but also to monitor their interactions in the cytoplasm and nucleus of the cells at a molecular level, and to characterise the subsequent cellular responses on a subcellular level. Spectroscopic signatures of DNA intercalation, binding and damage are clearly identifiable in the cell nucleus, and cellular responses such as the upregulation of anti-apoptotic proteins and cytoplasmic damage can be monitored. The technique has previously been employed to differentiate the two cancer cell lines, A549 and Calu-1 based on the spectroscopic signatures of their nucleoli, and in this study the differences of the responses of the two cell lines to DOX exposure are clearly identifiable in their post exposure spectroscopic signatures. Notably, due to the sensitivity of the detection system, Raman spectroscopy can detect the presence of the drug in the cytoplasm in the Calu-1 cell line, but not in A549, which is a key to understanding the difference in the cytotoxic responses, and therefore in cell resistance to the drug, coupled with the increased upregulation of anti-apoptotic proteins in the nucleus. The technique corroborates the results of classic cytotoxicity assays, bcl-2 monitoring using flow cytometry, ROS monitoring using confocal microscopy, but does so in a single, label free measurement, clearly indicating the benefits of the technique for high content screening and in vitro companion diagnostics.

\section{Acknowledgement:}

This work was supported by Science Foundation Ireland Principle Investigator Award 11/PI/1108. 


\section{References:}

[1] A. Paudel, D. Raijada, and J. Rantanen, Adv Drug Deliv Rev 89, 3-20 (2015).

[2] S. Cîntă Pînzaru, I. Pavel, N. Leopold, and W. Kiefer, J. Raman Spectrosc. 35, 338-346 (2004).

[3] H.J. Byrne, M. Baranska, G.J. Puppels, N. Stone, B. Wood, K.M. Gough, P. Lasch, P. Heraud, J. Sule-Suso, and G.D. Sockalingum, Analyst 140, 2066-2073 (2015).

[4] C. Knipfer, J. Motz, W. Adler, K. Brunner, M.T. Gebrekidan, R. Hankel, A. Agaimy, S. Will, A. Braeuer, F.W. Neukam, and F. Stelzle, Biomed. Opt. Express 5, 3252-3265 (2014).

[5] L.F. Carvalho, F. Bonnier, K. O'Callaghan, J. O'Sullivan, S. Flint, H.J. Byrne, and F.M. Lyng, Exp. Mol. Pathol. 98, 502-509 (2015).

[6] S. Feng, R. Chen, J. Lin, J. Pan, Y. Wu, Y. Li, J. Chen, and H. Zeng, Biosens. Bioelectron. 26, 3167-3174 (2011).

[7] H. Yao, Z. Tao, M. Ai, L. Peng, G. Wang, B. He, and Y. Li, Vib. Spectrosc 50, 193-197 (2009).

[8] H. Abramczyk, B. Brozek-Pluska, J. Surmacki, J. Jablonska-Gajewicz, and R. Kordek, Prog. Biophys. Mol. Biol. 108, 74-81 (2012).

[9] S. Lee, H. Chon, J. Lee, J. Ko, B.H. Chung, D.W. Lim, and J. Choo, Biosens. Bioelectron. 51, 238-243 (2014).

[10] I. R. Ramos, A. Malkin, and F. M. Lyng, Biomed Res Int 2015, 561242 (2015).

[11] N. Rashid, H. Nawaz, K.W. Poon, F. Bonnier, S. Bakhiet, C. Martin, J.J. O'Leary, H.J. Byrne, and F.M. Lyng, Exp. Mol. Pathol. 97, 554-564 (2014).

[12] F.B. Legesse, A. Medyukhina, S. Heuke, and J. Popp, Comput Med Imaging Graph 43, $36-43$ (2015).

[13] B. Kann, H.L. Offerhaus, M. Windbergs, and C. Otto, Adv. Drug Deliv. Rev. 89, 71-90 (2015).

[14] Z. Farhane, F. Bonnier, A. Casey, and H. J. Byrne, Analyst 140, 4212-4223 (2015).

[15] C. A. Owen, J. Selvakumaran, I. Notingher, G. Jell, L. L. Hench, and M. M. Stevens, J Cell Biochem 99, 178-186 (2006).

[16] J. T. Jorgensen, Trends Mol Med 21, 405-407 (2015).

[17] M. R. Trusheim and E. R. Berndt, Drug Discov Today 20, 1439-1450 (2015).

[18] S. Hrelia, D. Fiorentini, T. Maraldi, C. Angeloni, A. Bordoni, P. L. Biagi, and G. Hakim, BBA-REV BIOMEMBRANES 1567, 150-156 (2002). 
[19] S. M. Cutts, A. Nudelman, A. Rephaeli, and D. R. Phillips, IUBMB Life 57, 73-81 (2005).

[20] F. Yang, S. S. Teves, C. J. Kemp, and S. Henikoff, BBA REV CANCER 1845, 84-89 (2014).

[21] T. Yokochi and K. D. Robertson, Mol Pharmacol 66, 1415-1420 (2004).

[22] Y. Filyak, O. Filyak, S. Souchelnytskyi, and R. Stoika, Eur J Pharmacol 590, 67-73 (2008).

[23] T. Wojcik, E. Buczek, K. Majzner, A. Kolodziejczyk, J. Miszczyk, P. Kaczara, W. Kwiatek, M. Baranska, M. Szymonski, and S. Chlopicki, Toxicol In Vitro 29, $512-$ $521(2015)$.

[24] A. Rogalska, A. Gajek, M. Szwed, Z. Jozwiak, and A. Marczak, Toxicol In Vitro 25, 1712-1720 (2011).

[25] M. B. Wolf and J. W. Baynes, Biochim Biophys Acta 1760, 267-271 (2006).

[26] T. Moldoveanu, A. V. Follis, R. W. Kriwacki, and D. R. Green, Trends Biochem Sci 39, 101-111 (2014).

[27] S. J. Haikerwal, J. Hagekyriakou, M. MacManus, O. A. Martin, and N. M. Haynes, Cancer Lett. 368, 198-208 (2015).

[28] E.C. De Bruin and J.P. Medema, Cancer Treat. Rev. 34, 737-749 (2008).

[29] S. Elmore, Toxicol Pathol 35, 495-516 (2007).

[30] J. M. Hardwick and L. Soane, Cold Spring Harb Perspect Biol 5, (2013).

[31] C. Correia, S. H. Lee, X. W. Meng, N. D. Vincelette, K. L. Knorr, H. Ding, G. S. Nowakowski, H. Dai, and S. H. Kaufmann, Biochim Biophys Acta 1853, 1658-1671 (2015).

[32] A. Gimenez-Cassina and N. N. Danial, Trends Endocrinol Metab 26, 165-175 (2015).

[33] M. J. Roy, A. Vom, P. E. Czabotar, and G. Lessene, Br J Pharmacol 171, 1973-1987 (2014).

[34] P. A. Sotiropoulou, A. Candi, G. Mascre, S. De Clercq, K. K. Youssef, G. Lapouge, E. Dahl, C. Semeraro, G. Denecker, J. C.Marine, and C. Blanpain, Nat Cell Biol 12, $572-$ $582(2010)$.

[35] P. Hussar, M. Žuravskaja, and M. Kärner, Papers on Anthropology XXII 22, 63-67 (2013).

[36] G. Makin and C. Dive, TRENDS CELL BIOL 11, S22-S26 (2001).

[37] R. W. Johnstone, A. A. Ruefli, and S. W. Lowe, Cell 108, 153-164 (2002). 
[38] S. Caponi, L. Liguori, A. Giugliarelli, M. Mattarelli, A. Morresi, P. Sassi, L. Urbanelli, and C. Musio, Biophys Chem 182, 58-63 (2013).

[39] R. M. Mohammad, I. Muqbil, L. Lowe, C. Yedjou, H. Y. Hsu, L.T. Lin, M. D. Siegelin, C. Fimognari, N. B. Kumar, Q. P. Dou, H. Yang, A. K. Samadi, G. L. Russo, C. Spagnuolo, S. K. Ray, M. Chakrabarti, J. D. Morre, H. M. Coley, K. Honoki, H. Fujii, A. G. Georgakilas, A. Amedei, E. Niccolai, A. Amin, S. S. Ashraf, W. G. Helferich, X. Yang, C. S. Boosani, G. Guha, D. Bhakta, M. R. Ciriolo, K. Aquilano, S. Chen, S. I. Mohammed, W. N. Keith, A. Bilsland, D. Halicka, S. Nowsheen, and A. S. Azmi, SEMIN CANCER BIOL 35, Supplement, S78-S103 (2015).

[40] T. Qiu, L. Zhou, T. Wang, J. Xu, J. Wang, W. Chen, X. Zhou, Z. Huang, W. Zhu, Y. Shu, and P. Liu, Int J Mol Med 32, 593-598 (2013).

[41] P. Poornima, V. B. Kumar, C. F. Weng, and V. V. Padma, Food Chem Toxicol 68, 8798 (2014).

[42] Z. Farhane, F. Bonnier, A. Casey, A. Maguire, L. O'Neill, and H. J. Byrne, Analyst 140, 5908-5919 (2015).

[43] H.J. Byrne, P. Knief, M.E. Keating, and F. Bonnier, Chem. Soc. Rev. DOI:10.1039/C5CS00440C，(2016).

[44] F. Bonnier and H. J. Byrne, Analyst 137, 322-332 (2012).

[45] M. Boiret, D. N. Rutledge, N. Gorretta, Y. M. Ginot, and J. M. Roger, J Pharm Biomed Anal 90, 78-84 (2014).

[46] V. Vrabie, C. Gobinet, O. Piot, A. Tfayli, P. Bernard, R. Huez, and M. Manfait, Biomed Signal Process Control 2, 40-50 (2007).

[47] R. Hamid, Y. Rotshteyn, L. Rabadi, R. Parikh, and P. Bullock, Toxicol In Vitro 18, 703710 (2004).

[48] S. Al-Nasiry, N. Geusens, M. Hanssens, C. Luyten, and R. Pijnenborg, Hum Reprod 22, 1304-1309 (2007).

[49] R. D. Fields and M. V. Lancaster, Am Biotechnol Lab 11, 48-50 (1993).

[50] S. N. Rampersad, Sensors (Basel) 12, 12347-12360 (2012).

[51] S. Pietkiewicz, J. H. Schmidt, and I. N. Lavrik, J Immunol Methods 423, 99-103 (2015).

[52] S. H. Kaufmann and W. C. Earnshaw, Exp Cell Res 256, 42-49 (2000).

[53] G. Kroemer, L. Galluzzi, P. Vandenabeele, J. Abrams, E. S. Alnemri, E. H. Baehrecke, M. V. Blagosklonny, W. S. El-Deiry, P. Golstein, D. R. Green, M. Hengartner, R. A. Knight, S. Kumar, S. A. Lipton, W. Malorni, G. Nunez, M. E. Peter, J. Tschopp, J. 
Yuan, M. Piacentini, B. Zhivotovsky, and G. Melino, Cell Death Differ 16, 3-11 (2009).

[54] E. Brauchle, S. Thude, S. Y. Brucker, and K. Schenke-Layland, Sci. Rep. 4, 4698 (2014).

[55] E. Stephanova, T. Topouzova-Hristova, and R. Konakchieva, Toxicol In Vitro 22, 688694 (2008).

[56] H. Mizutani, S. Tada-Oikawa, Y. Hiraku, M. Kojima, and S. Kawanishi, Life Sci 76, 1439-1453 (2005).

[57] D. A. Gewirtz, Biochem Pharmacol 57, 727-741 (1999).

[58] S. Wang, S. Kotamraju, E. Konorev, S. Kalivendi, J. Joseph, and B. Kalyanaraman, Biochem J 367, 729-740 (2002).

[59] A. Costa, A. Scholer-Dahirel, and F. Mechta-Grigoriou, Semin Cancer Biol 25, 23-32 (2014).

[60] B. Halliwell, J Neurochem 97, 1634-1658 (2006).

[61] P.T. Schumacker, Cancer Cell 10, 175-176 (2006).

[62] H. Nawaz, A. Garcia, A. D. Meade, F. M. Lyng, and H. J. Byrne, Analyst 138, 61776184 (2013).

[63] H. H. Lin, Y. C. Li, C. H. Chang, C. Liu, A. L. Yu, and C. H. Chen, Anal Chem 84, 113120 (2012).

[64] T. Huser and J. Chan, Adv Drug Deliv Rev accepted manuscript 26 June 2015 DOI: 10.1016/j.addr.2015.06.011, (2015).

[65] F. Draux, P. Jeannesson, A. Beljebbar, A. Tfayli, N. Fourre, M. Manfait, J. Sule-Suso, and G. D. Sockalingum, Analyst 134, 542-548 (2009).

[66] A. Downes and A. Elfick, Sensors (Basel) 10, 1871-1889 (2010).

[67] I. Notingher, S. Verrier, H. Romanska, A. E. Bishop, J. M. Polak, and L. L. Hench, SPECTROSC-INT J 16, 43-51 (2002).

[68] N. Pravin and N. Raman, Inorg. Chem. Commun. 36, 45-50 (2013).

[69] N. Raman and S. Sobha, Inorg. Chem. Commun. 17, 120-123 (2012).

[70] B. Rafique, A. M. Khalid, K. Akhtar, and A. Jabbar, Biosens. Bioelectron. 44, 21-26 (2013).

[71] I. Notingher, Sensors 7, 1343-1358 (2007). 


\section{Graphical Abstract:}

Raman microspectroscopy is employed to investigate and compare the in vitro mechanisms of action of Doxorubicin and cellular resistances of cancer cell lines A549 and Calu-1.

Results show the potential of Raman not only to distinguish the different mechanisms of action and subcellular response but also to elucidate drug resistance in the different cell lines.
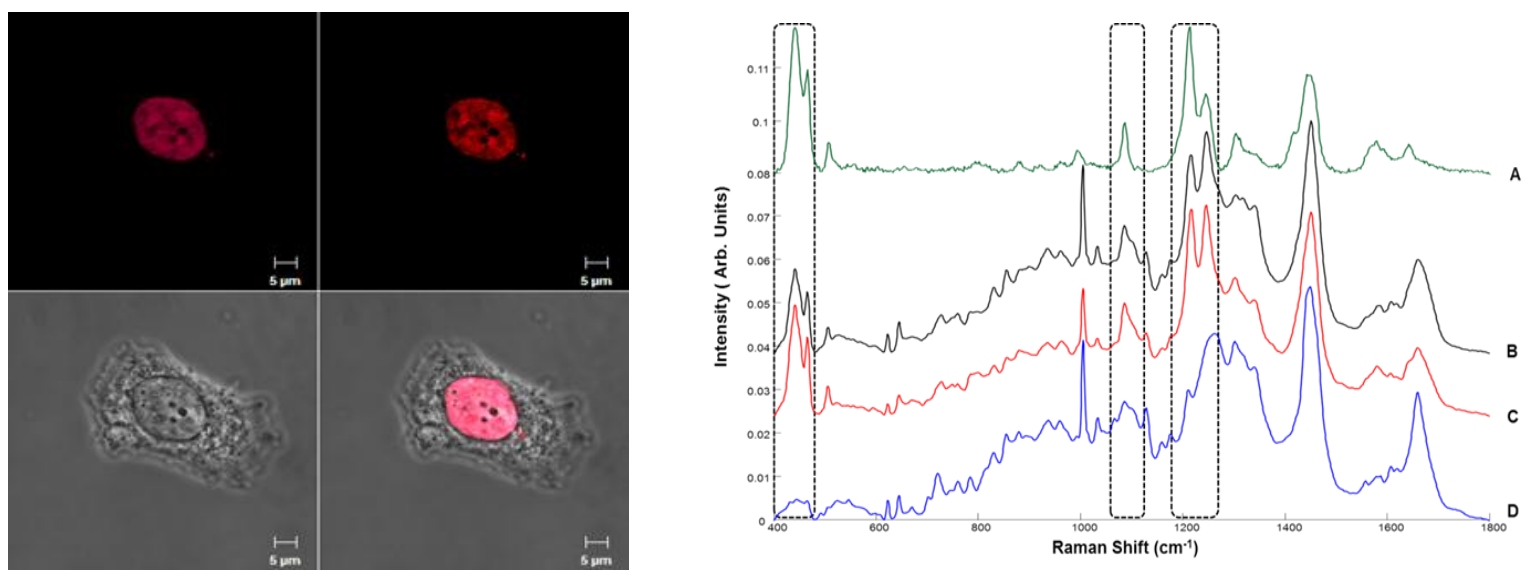